\title{
DEDUCTING BUSINESS EXPENSES DESIGNED TO INFLUENCE GOVERNMENTAL POLICY AS "ORDINARY AND NECESSARY": CAMMARANO v. UNITED STATES AND A BIT BEYOND
}

WHETHER profitmaking enterprises may treat the amounts they spend to encourage governmental policies favorable to their businesses as business expenses, deductible on corporate and individual income tax returns, represents an important facet of a recurrent national issue. ${ }^{1}$ The Internal Revenue Code's cryptic business-expense provision, section $162(a)$, makes deductible all spending which is "ordinary and necessary in carrying on a trade or business." Treasury regulations have long interpreted this language as excluding amounts spent "for lobbying purposes, the promotion or defeat of legislation, [and] the exploitation of propaganda other than trade advertising." The Supreme Court first passed upon the validity of these regulations in the 1941 case of Textile Mills Sec. Corp. v. Commissioner. It unanimously upheld the disallowance of deduction of public-relations and legal-research expenses incurred by a corporate taxpayer whose only business appeared to be lobbying before Congress pursuant to a contingent-fee contract entered into with German textile interests to obtain legislation returning sixty million dollars in properties seized by the United States during World War I. The Court's theory was that these expenses, even though clearly linked to business profitability, were still not "ordinary and necessary" because that language in the Code is sufficiently ambiguous to admit of the longstanding interpretation which the Treasury regulations had placed upon it. And the Court found no policy of Congress

1. See Andrews, Corporation Gring 180-81 (1952); Blalsdell, Aurgrica: Dearocracy Under Pressure (1957); SchriftGiesser, The Lobdyists 146-6S (1951). Several congressional investigations have been concerned with business expenditures in the political arena. See S. REP. No. 395, 85th Cong., 1st Sess. 201 (1957) (digesting reports of earlier business lobbying investigations). See generally Comment, 56 Y ALE LJ. 304 (1947). In 1958 business organizations filing under the Federal Regulation of Lobbying Act reported spending $\$ 2,047,657.41$ for directly contacting Congressmen, 15 Cong. Q. Alusaxac 680 (1959), undoubtedly only a small portion of the total amount spent to influence Government policy, id. at 678; Comment, 56 Y ALE L.J. 325-27 (1947) ; see H.R. REP. No. 3137, 81st Cong., 2d Sess. (1950) ; H.R. REp. No. 3138, 81st Cong., 2d Sess. 9 (1950) (at least $\$ 32$ million expended by business for legislative activity between January 1947, and Mlay 1950).

2. INT. REv. CODE OF 1954, \$ 162(a); see Deputy v. DuPont, 30 U.S. 488 (1940); Welch v. Helvering, 290 U.S. 111 (1933).

3. Treas. Reg. 45, art. 562 (1919) (now Treas. Reg. $\$ 1.162-15$ (c) (1959)). In substantially the same terms, these regulations have applied to corporate expenses since 1918 and to individual business expenses since 1938. Cammarano v. United States, 358 U.S. 498, 503 n.6 (1959). As early as 1915, the Treasury had ruled that amounts expended for lobbying were not ordinary and necessary. T.D. 2137, 17 TREAS. DEC INT. REV. 48, 57,58 (1915).

4. 314 U.S. 326 (1941). 
which "contravened" this interpretation.5 Although it therefore valiclated the regulations as applied, the Court characterized the taxpayer's arrangement, according to which it was to receive a percentage of the value of the property returned, as falling within a "family of contracts to which the law has given no sanction" - - citing cases holding contingent-fee lobbying contracts void as against public policy ${ }^{7}$-and as tending to spread "insidious influences through legislative halls" $; 8$ and the decision has been viewed by some commentators " and, seemingly, by the Court itself in a later dictum ${ }^{10}$ as limited to cases involving comparable contingent-fee lobbying before Congress. But the courts of appeals and the Tax Court have subsequently interpreted the decision more broadly, and have upheld the Treasury regulation as applied to a wide variety of expenditures. ${ }^{11}$

5. Id. at 338 ,

6. Id. at 339 .

7. Hazelton v. Sheckells, 202 U.S. 71 (1906) ; Trist v. Child, 88 U.S. (21 Wall.) 441 (1874).

8. 314 U.S. at 338. Some disagreement exists on whether such arrangements should be unenforceable without further inquiry. Compare S. REP. No. 395, 85th Cong., 1st Sess. 79 (1957), with H.R. REP. No. 3239, 81st Cong., 2d Sess. 30 (1951).

9. See Lurie, Deductibility of Illegal Expenses, N.Y.U. 11TH INST. ON FEv. TAx. 1189 (1953); Spiegel, Deductibility of Lobbying, Initiative and Refcrendtim Expenses: $A$ Problem for Congressional Consideration, 45 CALIF. L. REv. 1 (1957); Note, 54 HIARv. L. Rev. 698 (1941).

10. In Tank Truck Rentals, Inc. v. Commissioner, 356 U.S. 30 (1958), the Court noted that the business expense regulations involved in Textile Mills reflected "an administrative distinction "between legitimate business expenses and those arising from that family of contracts to which the law has given no sanction." Id. at 34. And in Commissioner v. Heininger, 320 U.S. 467 (1943), the Court oited Textile Mills in support of the proposition that "one who has incurred expenses for certain types of lobbying and political pressure activities with a view to influencing federal legislation has been denied a deduction." Id. at 473. (Emphasis added.) But see Webster, Dedictibility of Lobbying and Related Expenses, 42 A.B.A.J. 175 (1956) ("Lilly v. Commissioner, 343 U.S. 90 (1952) makes it clear that Textile Mills is based not on considerations of public policy but on the administrative interpretation of the statutory business expense section.").

11. American Hardware \& Equip. Co. v. Commissioner, 202 F.2d 126 (4th Cir. 1953) (contributions by a corporation for activity designed to obtain revisions in the tax laws); Roberts Dairy Co. v. Commissioner, 195 F.2d 948 (8th Cir. 1952) (same); Wm. T'. Stover Co., 27 T.C. 434 (1956) (reimbursement by a hospital supply corporation of the expenses of a newsman in flying to the United Kingdom to obtain background for articles opposing socialized medicine); Herbert Davis, 26 T.C. 49 (1956) (contributions to association operated to oppose referendum measure); The Mosby Hotel Co., 23 P.H Tax Ct. Mem. 920 (1954) (contributions by retail liquor corporations for a publicity campaign to prevent a state legislature from putting a prohibition referendum on the state election ballot); Smokey Mountains Beverage Co., 22 T.C. 1249 (1954) (corporatc expenses for the appearance of its president before state legislative committces); The MeClintockTrunkey Co., 19 T.C. 297 (1952) (corporate contributions to lobbying organizations and to the Washington Wholesalers' Beer Association which was active in opposing an initiative then before the legislature) ; Delaware Steeplechase \& Race Ass'n, 9 CCH Tax Ct. Mem. 893 (1950) (expenses for attorney to testify before congressional committee in opposition to federal legislation); Anthony Cornero Stralla, 9 T.C. 801 (1947) (payments by corporation to its Washington attorney for keeping it informed concerning current legislative develop. 


\section{Camprarano v. United States}

\section{The Decision}

The regulations did not come before the Supreme Court again for almost twenty years, but when they did the Treasury was sustained in sweeping terms. In Cammarano v. United States, ${ }^{12}$ decided in early 1959, the Treasury had disallowed deductions claimed on the individual returns of two partners in a wholesale beer distributing business. The deductions were for 886 dollars contributed by the partnership to a campaign opposing a referendum in the State of Washington which would have placed all retail sales of wine and beer exclusively in the hands of the state and would have seriously affected the wholesale distributing business. The contributions were made to a separate trust fund set up by a tax-exempt trade association of beer wholesalers, and the trust fund's total receipts of 53,500 dollars were funneled into an industrywide war chest of 231,257 dollars. In F. Stratiss \& Sons $v$. Commissioner, ${ }^{13}$ consolidated with Cammarano, the Treasury had denied a 9,000 dollar ileduction taken by a corporation, whose business was wholesaling liquor, for a contribution to a nonexempt corporation created by nine liquor dealers to coordinate their efforts and pool their aggregate contributions of 126,265 dollars in attempting to defeat an Arkansas prohibition referendum. All of the contributions in question in both cases were spent for the sole purpose of influencing the voters of the state through widespread advertising and other publicity. The Court saw no distinction between the individual and corporate deductions and the separate regulations applicable thereto. It had no dificulty in finding that the contributions were within the regulations' scope by rejecting, inter alia, the taxpayers' assertion that initiative proposals are not "legislation." 14

The major portion of the opinion is devoted to rejecting the taxpayers' contention that since adoption of the referendums would have destroyed their businesses, expenses in opposing them met any reasonable test of "ordinary" and necessary" and that, therefore, the Treasury regulations were invalid as applied to those expenses. ${ }^{15}$ The Court reiterated its Tertile Mills view that the regulations were a proper interpretation of an ambiguous Code provision. ${ }^{10}$ It emphasized that the regulations had "acquired the force of law" 17 because Congress had "repeatedly" reenacted the Code "without the slightest suggestion that the policy does other than precisely conform to its intent."18 This

ments affecting taxpayer's business); MIary E. Bellingrath, 49 B.T.A. 89 (1942) (cuntributions underwriting opposition to proposed legislation).

12. 358 U.S. 498 (1959); see Sharp, Reflection on the Disallowance of Income Tu.r Deductions for Lobbying Expenditures, 39 B.U.L. REv. 365 (1959); The Supreme Conrt. 1958 Term, 73 Harv. L. Rev. 84, 191 (1959); 58 MIrCH. L. Rev. 142 (1959); Note, th VA. L. REv. 112 (1960).
13. 358 U.S. 498 (1959).
14. Id. at 504 .
15. Brief for Petitioners, p. 15, Cammarano v. United States, 358 U.S. 498 (1959).
16. 358 U.S. at 508 .
17. Id. at 510 .
18. Id. at 508-09. 
assumption of reenactment was warranted, said the Court, because of the "unambiguous regulatory language," the regulations' "continuous existence" since 1918, and the fact that they had been "consistently construed" by the courts. ${ }^{10}$

The Count also disposed of the contention, premised upon Commissioncr $v$. Heininger, ${ }^{20}$ that expenses so clearly related to business survival and profitability can be disallowed only on grounds of a "sharply defined" national or state policy announced outside the revenue laws. ${ }^{21}$ In rejecting this argument, the Court seemed to be articulating a new rationale and stating that even if the expenses met the "ordinary and necessary" test, denial of deduotion was proper because the regulations "themselves constitute an expression of a sharply defined national policy, further demonstration of which may be found in other sections of the Internal Revenue Code."22 The ather sections of the Code referred to, which had received only footnote attention in Textile Mills, ${ }^{23}$ were those withholding exempt status from, and denying deductibility of contributions to, charitable-educational organizations which engage in substantial legislative activity. ${ }^{24}$ In thus concluding that Congress had evidenced an intention to prevent public subsidization of legislative activity through tax deductions, ${ }^{20}$ the Court followed, at least in part, a notion of a congressional policy of "tax equilibrium" in the political arena requiring that deductions not be allowed which would be unavailable to taxpayers undertaking similar activities not related to trades or businesses. ${ }^{26}$

19. Id. at 511 .

20. 320 U.S. 467 (1943) (legal expenses incurred in resisting issuance by Postmaster General of fraud order accorded deductibility). The rule enunciated in this opinion had been followed in a number of decisions. See, e.g., Tank Truck Rentals, Inc. v. Commissioner, 356 U.S. 30 (1958); Lilly v. Commissioner, 343 U.S. 90 (1952) ; J. Rossman Corp. v. Commissioner, 175 F.2d 711 (2d Cir. 1949).

21. 358 U.S. at 508.

22. Ibid.

23. 314 U.S. 326,338 n.18 (1941).

24. 358 U.S. at 512; see INT. Rev. Code of 1954, § 501 (c) (3).

25. 358 U.S. at 512 . The Court enunciated this proposition by adopting a statement made by Judge Learned Hand in Slee v. Commissioner, 42 F.2d 184 (2d Cir. 1930).

26. See Brief for Respondents, p. 36, Cammarano v. United States, 358 U.S. 498 (1959) (" $[A]$ tax equilibrium exists. If the expenses of the business community werc to become deductible, this tax equilibrium would be upset. While the business community could deduct their expenses, all others could not."). Expenditures designed to promote the political-legislative ends of professional groups, technically outside the "business community," are presumably included within the Treasury's notion of "expenses of the business community" and are subsumed by the concept set forth in text of expenses "related to trades or businesses." Contributions to labor and farm organizations-extremely active legislatively, see McCune, Farmers in Politics, Annals, Sept. 1958, p. 41; Carcy, Organizcd Labor in Politics, id. at 52; 15 Cong. Q. Almanac 678 (1959), and exempt from income tax, INT. REv. CODE of 1954, $\$ 501$ (c) 5-are similarly deductible only as business expenses. See I.T. 2888, XIV-1 Cum. Bull. 54 (1935). All such expenditures are not treated separately in this Comment which, like Cammarano, focuses on deductions claimcd by businessmen. 


\section{The Decision's Rationale: A Brief Critique}

The notion that Congress had adopted the Treasury's position by reenacting the "ordinary and necessary" provision several times without change constitutes the foundation of the opinion. The reenactment doctrine, which rests on the doubtful assumption that Congress' repeated reenactment of a statute is "taken with knowledge of the construction placed upon the section by the official charged with its administration,"27 has been vigorously criticized in the past ${ }^{28}$ and is particularly questionable as applied in Cammarano. Most doubtful is the Court's view that the regulations had been "consistently construed." As noted in Cammarano, only the reenactments which occurred prior to the expenditures involved in that case could "conclusively demonstrate," if any reenactment could, "the propriety of an administrative and judicial interpretation and application."'29 But at the time of those reenactments, the last of which occurred in 1939 , there did exist, to a considerable degree, the "conflict between administrative and judicial interpretation of the statute" which, according to Cammarano, would lead to the conclusion that "no reliable inference as to Congress' intent" could be drawn from reenactment. ${ }^{30}$ Prior to the 1939 reenactment, which preceded the 1941 Textile Mills decision, only the Ninth Circuit in a single 1936 case $^{31}$ and the Fourth Circuit in Tertile Mills ${ }^{32}$ itself had unequivocally relied upon the regulations, while the Boand of Tax Appeals, which decided most of the earlier cases, ignored the regulations for the most part and often found expenses for political-legislative purposes "ordinary and necessary." M3 Moreover, if the 1954 reenactment can be

27. Massachusetts MIut. Life Ins. Co. v. United States, 288 U.S. 269, 273 (1933) (cited by the Cammarano Court, 358 U.S. at 511).

28. See, e.g., Griswold, A Summary of the Regulations Problem, 54 HARs. L. Rev. 398 (1941); Paul, Use and Abuse of Tax Regulations in Statufory Construetion, 49 Yule L.J. 660 (1940) ; Surrey, The Scope and Effect of Treasury Regulations Under the Income, Estate and Gift Taxes, 88 U. PA. L. REv. 556 (1940). The doctrine was argued before the Textile Mills Court but not relied upon in the decision Brief for Respondent, p. 14, Textile Mills Sec. Corp. v. Commissioner, 314 U.S. 326 (1941).

29. 358 U.S. at 510.

30. Id. at $510-11$.

31. Sunset Scavenger Co. v. Commissioner, 84 F.2d 453 (9th Cir. 1936). In an carlicr decision, the same court, in denying deduction of contributions to a lobbying organization, adverted to, but did not rely upon, the regulations. Old Mission Portland Cement Co. $:$ Commissioner, 69 F.2d 676 (9th Cir. 1934).

32. Commissioner v. Textile Mills Sec. Corp., 117 F.2d 62 (4th Cir. 1940).

33. Allowing deduction: Emery, Bird, Thayer Dry Goods Co., 20 B.T.A. 796 (1930); Best Brewer Co., 16 B.T.A. 1354 (1929); G. T. Wofford, 15 B.T.A. 1225 (1929); Los Angeles \& S.L.R.R., 18 B.T.A. 168 (1929); Hirsch-Weis Mfg. Co., 14 B.T.A. 796 (1928); George Ringler \& Co., 10 B.T.A. 1134 (1928); Independent Brewing Co., 4 B.T.A. 870 (1926). See also Lucas v. Wofford, 49 F.2d 1027 (5th Cir. 1931); Texas \& Pac. Ry. v. United States, 72 Ct. Cl. 629, 52 F2d 1040 (1931). Denying deduction : H. R. Cullen, 41 B.T.A. 1054 (1940); Lelia S. Kirby, 35 B.T.A. 578 (1937) (not mentioning the regulations but citing one decision which rested on them and two which did not): Mrs. Wm. P. Kyne, 35 B.T.A. 202 (1936) (mentioning the regulations only secondarily); The Adler Co., 10 B.T.A. 849 (1928). 
thought to indicate retroactive congressional approval of the regulations as applied to pre-1954 expenditures, the Court's broad view of that reenactment - "significant as indicating satisfaction with the interpretation consistently given the statute by the Regulations . . .34-would not seem warranted. Textile Mills, because of its emphasis upon the contingent-fee nature of the arrangement involved, hardly indicates with clarity an end to the prior judicial-administrative conflict in interpretation. Only the lower courts, in some eight decisions rendered in the period from 1941 to 1954, clearly held that this era of conflict was over. ${ }^{35}$ Even if Congress was aware of so few holdings, ${ }^{10}$ that body may have nonetheless thought that only a narrow view of Tcxtilc Mills correctly and definitively interpreted the regulations. ${ }^{37}$

The doctrine that Congress had reenacted the Treasury's position seems particularly tenuous when used to disallow the expenses in Cammarano; the Treasury acquiesced in a 1944 Tax Court decision ${ }^{\text {ss }}$ allowing deduction of expenditures incurred to influence state-wide voting on a state constitutional amendment until May 22, 1958, ${ }^{30}$ the day certiorari was granted in Strauss. ${ }^{40}$ And the Court's footnote, stating that the "Commissioner and the Tax Court have been entirely consistent in their position that expenditures connected with initiative-as in the present cases-are not deductible," 41 seems unpersuasive. ${ }^{42}$ Of the cases cited by the Court, the two Tax Court cases in fact in. volved attempts to influence legislative decisions, not state-wide initiatives : : $^{\text {it }}$ in one Ninth Circuit case which did involve an initiative the court did not rely upon the regulations ${ }^{44}$ and the other appellate case in which expenditures

34. 358 U.S. at $\mathbf{5 1 0 .}$

35. See cases cited note 11 supra.

36. Cf. Brief for Petitioners, pp. 37-39, Textile Mills Sec. Corp. v. Commissioner, 314 U.S. 326 (1941).

37. See S. REP. No. 395, 85th Cong., 1st Sess. 229-31 (1957) (staff memoratudun indicating doubt as to the correct interpretation).

38. Luther Ely Smith, 3 T.C. 696 (1944), acq., 1944 Cum. Bunt. 26.

39. Rev. Rul. 58-255, 1958-1 Cun. Burl. 91.

40. Brief for Petitioners, p. 47 n.19, Cammarano v. United States, 358 U.S. 498 (1959).

41. 358 U.S. at 507 n.10.

42. The Commissioner certainly had not been consistent. He had issued special rulings to a North Carolina taxpayer and to a Colorado taxpayer according deductibility to expenditures made to defeat prohibition measures in those states. Record, pp. 39-43, Cammarano v. United States, 358 U.S. 498 (1959).

43. In McClintock-Trunkey Co., 19 T.C. 297 (1952), the taxpayer had contributed to the Washington Wholesalers' Beer Association which at that time was attempting to persuade the legislature not to put a proposed initiative measure on the state-wide ballot. In Mosby Hotel Co., 23 P-H Tax Ct. Mem. 920 (1954), the contributions in issue were made to an organization "formed for the purpose of conducting a campaign to repeal the prohibition laws of the State of Kansas," laws which had been enacted by the legislature and which, presumably, could be repealed by that body. These cases are cited by the Cammarano Court at 358 U.S. at 506, 507 n.10.

44. Old Mission Portland Cement Co. v. Commissioner, 69 F.2d 676, 681 (9th Cir. 1934) (cited in Cammarano, 358 U.S. at 506). 
were made to influence voters in an initiative was decided in 1956, after the expenditures in the instant case and after the 1954 reenactment. ${ }^{* 5}$ Nor does the asserted "unambiguous language" or the "continuous existence" of the regulations lend much greater support to the Court's argument that Congress consciously adopted the regulations. During most of the period since their promulgation in 1918, and at the time of Cammarano, the regulations were listed under charitable contributions rather than under business deductions and bore the title "Contributions or Gifts,"16 and lower courts have not found Code provisions governing charitable-educational organizations, virtually identical with these regulations, ${ }^{47}$ "unambiguous."18 Taking all these factors together, it seems reasonable to conclude that the reenactment doctrine does not properly apply to clothe the Treasury regulations with the force of law.

In addition, and for the same reasons, the regulations cannot be the basis of a "sharply defined national policy" requiring disallowance of the Cammarano expenditures. Also open to dispute is the Court's view that the charitable-education sections of the Code further demonstrate such a policy. True, the Code specifically denies exempt status to charitable-educational organizations engaging to a substantial degree in certain political-legislative activities 10 and disallows deduction of contributions to such organizations, ${ }^{, 0}$ apparently

45. Revere Racing Ass'n v. Scanlon, 232 F.2d 816 (1st Cir. 1956) (cited by the Cammarano Court, 358 U.S. at 506). Mforeover, this decision placed principal reliance not on the regulations but on a rule that expenses designed to give a possible opportunity to do business in the future were not ordinary and necessary, a rule derived from MreDonald v. Commissioner, 323 U.S. 57 (1944) (expenses by an individual taxpayer in his judgeship, election campaign are a capital investment not deductible as an ordinary and nccessary business expense). In Herbert Davis, 26 T.C. 49 (1956), however, a case not cited by the Camnzarano Court, a deduction for contributions to an association opposing a referendum before the voters was denied.

46. See Textile Mrills Sec. Corp. v. Commissioner, 314 U.S. 326, 357-58 (1941). The regulations before the Cammarano Court were $\$ \S 29.23(0)-1$ and 29.23(9)-1 of Trcasury Regulation 111 promulgated under the Internal Revenue Code of 1939. The regulations under the 1954 Code, adopted April 1958, by T.D. 6291, are listed in Treasury Regulations \$1.162-15(c) under \$ 162 of the Code, the "ordinary and necessary" business expense section.

47. Compare INT. REv. CODE OF 1954, $\$ 501$ (c)3, 170(c), with regulations cited note 46 supra.

48. See the varying treatment accorded the League of Women Voters in League of Women Voters v. United States, No. 232-56, C.. C., January 20, 1980; Liberty Nat"l Bank \& Trust Co. v. United States, 122 F. Supp. 759 (W.D. Ky. 1954); Henrieut T. Noyes, 31 B.T.A. 121 (1934). Compare Seasongood v. Commissioner, 227 F.2d 907 (6th Cir. 1955), with Faulkner v. Commissioner, 112 F.2d 987 (1st Cir. 1940). The cuurts have had similar difficulties under provisions exempting charitable-educational organizations from social security requirements; since 1954, 501 (c) 3 organizations have been so exempted. INT. REv. CODE of 1954, $\$ 3121$ (b)9(B); see Better Business Bureau v. Inited States, 326 U.S. 279 (1945) ; Lord's Day Alliance v. United States, 65 F. Supp. 62 (E.D. Pa. 1946) ; National Campaign Comm. v. Rogan, 69 F. Supp. 679 (S.D. Cal. 1945): Massachusetts Civic League v. United States, 59 F. Supp. 346 (D. Mrass. 1945).

49. INT. Rev. CODE of 1954, § 501 (c)3.

50. INT. Rey. CODE OF 1954, § 170 (c). 
indicating a congressional view that organizations lose their charitable-educational character when they engage in substantial political-legislative activities. But the separate treatment in the Code of business leagues and trade associations and contributions to them contains no such limitation on political-legislative activities. ${ }^{51}$ Since these organizations have for decades been notoriously active lobbyists, ${ }^{52}$ the omission of such a limitation is pointed and may be viewed as manifesting a congressional design to allow business deductions irrespective of legislative-political activities.

Furthermore, it would not seem possible to locate a "sharply defined" congressional or state policy outside the revenue laws which would warrant the Cammarano disallowance. ${ }^{53}$ The Treasury asserted in its brief in Cammarano that various congressional committee reports evidencing concern with the magnitude of business outlays for lobbying buttressed the theory that Congress had adopted a policy of "tax equilibrium." 54 These reports, however, were of investigations looking toward the enactment or improvement of the Regulation of Lobbying Act, which provides for the registration of lobbyists and disclosure of their expenses, ${ }^{55}$ not toward the effectuation of any policy against public subsidization through the tax laws. And since Congress failed to impose more stringent controls on lobbying, it is equally tenable to assert that Congress would not approve the additional inhibition imposed by denial of tax deductibility for legislative-political expenses.

Nor would the Federal Corrupt Practices Act, which prohibits contributions by corporations to support federal election campaigns, ${ }^{\mathbf{D}}$ seem to delineate a "sharply defined" congressional policy bearing on the Cammarano expenditures. Although one premise upon which this act is apparently based-that the voter is better able to act without propaganda distractions ${ }^{67}$-might seem to

51. INT. Rev. CODE OF 1954, § 501 (c)3.

52. See Schriftgiesser, The Lobeyists 101 (1951); Lenhart \& Schriftgiesser, Management in Politics, Annals, Sept. 1958, p. 32. In 1959, for example, scveral of these organizations regarded the enactment of the Labor-Management Reporting and Disclosure Act of 1959 as a substantial victory. 15 Cong. Q. Almansac 674-75 (1959). They also claimed several legislative victories in 1958. 14 Cong. Q. Alsanac 622 (1958).

53. Under prior decisions, it appeared that such a policy could be found only outside the revenue laws. See Lilly v. Commissioner, 343 U.S. 90 (1952); Commissioner v. Heininger, 320 U.S. 467 (1943).

54. See Brief for Respondents, pp. 32-35, Cammarano v. United States, 358 U.S. 498 (1959); note 26 supra.

55. 60 Stat. 840-41 (1946), 2 U.S.C. $\S \S 264,267$ (1958); see Futor, An Analysis of the Federal Lobbying Act, 10 FED. B.J. 366 (1949) ; Zeller, The Federal Regulation of Lobbying Act, 42 Ax. PoL. Scr. Rev. 239 (1948); Comment, 56 Y ALE L.J. 304 (1947).

56. 18 U.S.C. § 610 (1958); see Bicks \& Friedman, Regulation of Federal Election Finance: A Case of Misguided Public Morality, 28 N.Y.U.L. Rev. 975 (1953); Bottomly, Corrupt Practices in Political Campaigns, 30 B.U.L. Rev. 331 (1950); Hazard, II Takics Money To Get Elected, Atlantic Monthly, Feb. 1960, p. 92. Contributions by labor unious are also prohibited.

57. See Nye, The Influence of Money in Political Campaigns, 74 Conc. Rec. 2158 (1931) ; Ostrogorskil, Denocracy and the Party System 223-24 (1926). 
support a contrary position, another purpose for the congressional prohibition, protection of shareholders from expenditures of corporate funds for causes with which they may not agree, 58 appears applicable only to campaign contributions, which underwrite the entire range of policies advocated by the candidate or party to which contributions are made. Hence, expenditures to defeat a referendum, which concerned a single well-defined issue clearly in the interest of all shareholders, would not run counter to this second purpose. The prohibition on corporate campaign contributions seems also designed to prevent the purchase of political favors by wealthy interests, ${ }^{80}$ and this policy would not seem frustrated by Cammarano-type expenditures designed to influence referendums which have no such effect upon elected officials. Moreover, because of free speech guarantees, such expenditures probably could not constitutionally be brought within the prohibitions of the Corrupt Practices Act. ${ }^{60}$ Finally, the expenditures in Cammarano (although not in Strauss) were by individuals to which a major aspect of the rationale of the Corrupt Practices Act-diminishing the political power of the managers of retained corporate earnings ${ }^{61}$-is inapplicable.

In Arkansas, a "sharply defined" policy against the deduction of the Strauss expenditures might have been found in a statute prohibiting any corporation or corporations, either individually or collectively, from expending more than 25,000 dollars in any initiative campaign. ${ }^{62}$ The deduction of expenditures made in violation of this statute, as the Stranss expenditures well might have been, ${ }^{63}$ would, as did the deduction claimed in the leading case of Tank Truck Rentals Inc. v. Commissioner, "frustrate sharply defined . . . state policies proscribing particular types of conduct . . . ." But the State of VVashington, where Cammarano itself arose, has no such statute, and, perhaps in the interest of nationwide uniformity, the Court did not narrow its decision to affect only

58. See S. ReP. No. 99, 81st Cong., 1st Sess., pt. 2, at 62 (1949).

59. Nye, sipra note 57. Contributions may be made in return for a definite promise of political favor. See Key, Poltrics, Parties, and Pressure Groups 469-73 (2d ed. 1948) ; Overacker, Dirty Money and Dirty Politics, New Republic, Sept. 11, 1950, p. 11.

60. Cammarano v. United States, 358 U.S. 498, 513 (1959) (concurring opinion of Douglas, J.) ; see United States v. Harriss, 347 U.S. 612 (1954). See generally Sunderland, Taxation of Free Speech, 26 U. CEI. L. Rev. 109 (1958).

61. See Bicks \& Friedman, Regulation of Federal Election Finance: A Case of Misguided Morality, 28 N.Y.U.L. Rev. 975 (1953). See also Herrno, TuE Pouitics of DeATOCRACY 341 (1940).

62. Ark. Stat. ANn. $\$ 3-1303$ (1956). For a comprehensive survey of state legislation dealing with corrupt practices, see Bottomly, Corrupt Practices in Political Compaigns, 30 B.U.L. REv. 331 (1950).

63. Although the statute seems not to have been judicially construed, the corporations in Strauss, acting collectively, spent 126,265.84 dollars through an intermediary for a "campaign .... in conection with the submission of ... [a] Jaw . . . to the vote of the people by initiation . ..." 358 U.S. at 502; see ARk. Stat. Awn. \& 3-1303 (19:6). For such expenditures above the maximum $\$ 25,000$ the statute imposes criminal sanctions.

64. 356 U.S. 30 (1958).

65. Id. at 33 . 
initiative or referendum expenditures in those few states having statutes similar to the Arkansas provision. ${ }^{66}$

\section{The Scope of Cammarano}

The Treasury has reacted to Cammarano by issuing a new set of regulations, which more fully elaborate the basic terms of those which the Court lad before it in Cammarano, ${ }^{67}$ and, apparently, by adopting a course of more vigorous enforcement. ${ }^{68}$ It may thus be anticipated that the principles announced by the Court in that case will be further tested, especially since the scope of the decision cannot readily be predicted. Some of the language of the Court is exceedingly broad, such as its quotation from an opinion by Judge Learned Hand declaring that "political agitation as such is outside the statute, however innocent the aim . . . . Controversies of that sort must be conducted without public subvention ...." ${ }^{60}$ This and other language ${ }^{70}$ has been viewed

66. See Bottomly, supra note 62 , at 350 (appendix collecting state statutes). This Arkansas statute and those similar to it may well raise first amendment problems. See note 60 sitpra.

67. Expenditures for lobbying purposes, for the promotion or defeat of legislation, for political campaign purposes (including the support of or opposition to any candidate for public office), or for carrying on propaganda (including advertising) related to any of the foregoing purposes are not deductible from gross income. For exaupls. the cost of advertising to promote or defeat legislation or to influence the public with respect to the desirability or undesirability of proposed legislation is not deductible as a business expense, even though the legislation may dircetly affect the taxpayer's business. On the other hand, expenditures for institutional or "good will" advertising which keeps the taxpayer's name before the public are generally deductible as ordinary and necessary business expenses provided the expenditures are related to the patronage the taxpayer might reasonably expect in the futurc. For example, a deduction will ordinarily be allowed for the cost of advertising. which keeps the taxpayer's name before the public in connection with encouraging contributions to such organizations as the Red Cross, the purchase of Unitcd States Savings Bonds, or participation in similar causes. In like fashion, expenditures for advertising which present views on economic, financial, social, or other subjects of a general nature but which do not involve any of the activities specified in the first sentence of this subparagraph are deductible if they otherwise meet the requirements of the regulations under section 162 .

Treas. Reg. $\S 1.162-15$ (c) (1) (1959). These regulations were finally adopted by T.D. 6435, 1960 INT. Rev. Bui. No. 4, at 7. It had originally been proposed, 21 Fed. Regr. 5095 (1956), withdrawn, and reproposed, 24 Fed. Reg. 7584 (1959).

68. See Spofford, The Impact of Some Recent Developments in Tart Litigation and Legislation, 37 TAXES 1068, 1069 (1959); Washington Tax Talk, 37 TAxEs 1036 (1959). Lobbying groups have expressed considerable concern over the possible impact of the new regulations on their activities. N.Y. Times, Oct. 18, 1959, p. 83, col. 3; Wall Strect Journal, Sept. 30, 1959, p. 1, col. 5.

69. 358 U.S. at 512, quoting Slee v. Commissioner, 42 F.2d 184, 185 (2d Cir. 1930) (contributions to the American Birth Control League, which claimed tax exempt statuw as a charitable organization, not deductible). The Treasury had quoted the same language from Slee in its brief. Brief for Respondents, p. 35.

70. The Court went on to state that "the Regulations here contested appear to us to be but a further expression of the same sharply defined policy." 358 U.S. at 512 . 
by some as an unqualified endorsement of the theory of a far-reaching "tax equilibrium" policy. ${ }^{71}$ Insofar as the Court relied on a finding of a "sharply defined" policy within the tax laws, its opinion seems potentially broader than previous business-expense cases resting upon a finding of such a policy in a specific declaration of Congress or a state outside the revenue laws $;^{72}$ the Court presumably is itself free to define the policy's outer limits. Insofar as the opinion adopts the Treasury regulations as "the law," its full reach is perhaps as uncertain as the necessarily vague terms in which those regulations are cast. ${ }^{73}$

The scope of the decision must be assessed in light of the nature of business expenditures in the legislative and political arena. Such expenditures may vary widely in accordance with (1) the stage of the political process at which influence is sought to be exerted, (2) the means of exerting influence adopted, and (3) the organizational structure through which these means are attempted. Thus, businesses may seek election or defeat of individual candidates or parties in state or federal balloting, adoption or rejection of a particular measure by a state legislature or by Congress, success or failure of a state referendum, the issuance of a ruling or order of a state or federal administrative agency, or construction, enforcement, or nonenforcement of a given measure by state or federal executive officers. The method adopted may include traditional forms of direct lobbying before legislators or other governmental officers, advertising or publicity campaigns directed to the public generally, testimony and other formal appearances before legislative or executives bodies, and preparation of research and ostensibly factual material for presentation to particular legislators and officers of the government or to the public. The channel through which the expenditure is made may be a nonexempt organization created by several enterprises for the purpose of attaining the objective sought, an exempt charitable-educational organization, business league or trade association with other continuing functions, or, finally, a single enterprise may devote its own resources and personnel to achieve the objective. This Comment will seek to examine these various possibilities and suggest how they will or should be treated in the wake of Cammarano and the new Treasury regulations.

\section{Electoral}

\section{Stage of the Political Process}

Although Cammarano, like Textile Mills, did not involve expenses for election campaigns, the regulations before the Court have since 1918 stated that

71. Sharp, Reflection on the Disallowance of Income Tax Deductions for Lobbyin! Expenditures, 39 B.U.L. Rev. 365 (1959); 58 Mrcr. L. Rev. 142 (1959); Note, to VA. I.. REv. 112 (1960); see note 26 stpra and accompanying text.

72. Lilly v. Commissioner, 343 U.S. 90, 97 (1952); see Tank Truck Rentals, Inc. v. Commissioner, 356 U.S. 30 (1958) ; Hoover Motor Express Co. v. Commissioner, 356 U.S. 38 (1958). See generally Bittker, Cases on Federal Ixcosre Estate aNd Girt TAxAtio: 249-51 (2d ed. 1958).

73. See Treas. Reg. $§ 1.162-15$ (c) (1959). 
"contributions for campaign expenses" are not ordinary and necessary." The post-Cammarano regulations would disallow "expenditures . . . for political campaign purposes (including the support of or opposition to any candidate for public office) ...."75 This broader statement would seem fully justified since support of candidates and parties appears insufficiently related to business survival and profitability to warrant its being characterized as ordinary and necessary. ${ }^{76}$ The favorable impact upon the business donor of expenditures for the purpose of electing or defeating certain legislators or officials is more speculative than are expenditures designed, for example, to influence the outcome of a referendum. The donor's candidates may not achieve sufficient control of the machinery of government to make certain that policies enhancing his business profitability will be adopted, and even those who do may turn against him once in office. In addition, support for a candidate or party necessarily carries with it support for many policies and programs in which the donor has no business interest whatever, and, to the extent that this is the case, expenditures for such support are even more certainly not ordinary and necessary.

Furthermore, at least when the business is incorporated, such expenditures would contravene "sharply defined" governmental policies. In the case of federal elections, the Corrupt Practices Act prohibits all corporate campaign donations, ${ }^{77}$ and most states have enacted similar prohibitions applicable in state elections. ${ }^{78}$ Even when campaign support is sufficiently disguised to avoid these prohibitions, the Treasury would nevertheless seem warranted in denying deductibility. The underlying policy of these legislative enactments seems equally applicable whether the support takes the form of direct corporate contributions to a campaign fund or one of the more subtle, and more practiced, forms. ${ }^{70}$

74. See Textile Mills Sec. Corp. v. Commissioner, 314 U.S. 326, 337 (1941).

75. Treas. Reg. § $1.162-15$ (c) (1959).

76. These expenses would seem to be ordinary in the sense of "normal, ustual, or customary" and "of common or frequent occurrence in the type of business involved," Deputy v. DuPont, 308 U.S. 488, 495 (1940). See also Welch v. Commissioner, 290 U.S. 111 (1933). But they would not seem to be "payments by and with reasonable expectations that the business of ... [taxpayer] would be advanced." Smith-Bridgman \& Co., 16 T.C. 287, 295 (1951). These payments "clearly come within the class of contributions from which only indefinite and indirect benefit may be expected . . ." Old Mission Portland Cement Co. v. Commissioner, 69 F.2d 676 (9th Cir. 1934). See also Emery, Bird, Thayer Dry Goods Co., 20 B.T.A. 796 (1930) ; Hirsch-Weis Mfg. Co., 14 B.T.A. 796 (1928).

77. 18 U.S.C. $\S 610$ (1958).

78. See, e.g., N.Y. Pen. Law $\S 671$; Pa. Stat. Ann. tit. 25, $\$ \$ 3225$ (b), 3543 (Supp. 1958).

79. The federal prohibition on corporate campaign contributions has been largely ineffective. Contributions once made directly by the corporation are now made by corporate officials and their families, through various national business groups or through the purchase of "public interest" advertisements. Bicks \& Friedman, Regulation of Fcdcral Election Finances: $A$ Case of Misgnided Morality, 28 N.Y.U.L. REv. 975, 995 (1953). Although state prohibitions may be broadly worded, they do not appear to have been ex- 


\section{Legislative-Congress, State Legislature, or Statc Refercudum}

Textile Mills and Cammarano would seem conclusively to deny deductibility to business expenses designed to ensure adoption or defeat of a legislative bill. The regulations which the Court upheld in those cases contained terms identical to those of the recently promulgated regulations; expenditures for "lobbying purposes" and for the "promotion or defeat of legislation" are not deductible. ${ }^{80}$ Giving the terms "lobbying" and "promotion or defeat of legislation" their accepted meaning, 81 it would seem, therefore, that any spending by business designed to influence the outcome of a bill in Congress or a state legislature is nondeductible. Furthermore, Cammarano appears dispositive of the proposition that state referendums are "legislation" and subject to the regulations equally with bills before a legislature. ${ }^{82}$ The new regulations adopt this broad view in defining "promotion or defeat of legislation" to include "attempting to ... influence members of a legislative body . . . or . . . influence the public to approve or reject a measure in a referendum, initiative, vote on a constitutional amendment, or similar procedure." 83

\section{Administrative or Executive}

To date, it appears that the Treasury has not sought to disallow deductions for expenditures designed to influence the decisions of administrative and executive bodies. ${ }^{84}$ Yet nothing in Cammarano indicates that the announced policy is not equally applicable beyond the legislative stage, during the equally crucial stage of interpretation, construction, and enforcement of legislative acts or exercise of executive powers. Such an extension of Cammarano might be viewed as particularly desirable in light of recent disclosures of business spending to influence regulatory commissions ${ }^{85}$ and because a policy designed to

tensively invoked. See, e.g., PA. Stat. Axx. tit. 25, $\$ 3225$ (corporate contributions an not be made "directly or through any other person") N.Y. PEN. LAw $\$ 671$ ("directly or indirectly").

80. Compare Treas. Reg. 74, art. 262 (1929), and Treas. Reg. 111, $\$ 29.23(0)-1$ (1943), with Treas. Reg. \$ 1.162-15(c) (1959).

81. "Lobbying" certainly encompasses pressure activities in the presence of the chacting body, United States v. Harriss, 347 U.S. 612 (1954); United States v. Rumley, 345 U.S. 41, 47 (1953), although it probably includes much more today, Zeller, The Federal Regulation of Lobbying Act, 42 Axr. PoL. ScI. Rex. 239, 268 (1948) ; Celler, Pressure Gronss in Congress, Annals, Sept. 1958, p. 1, at 3.

82. "We think that initiatives are plainly 'legislation' within the Regulations." Cammarano v. United States, 358 U.S. 498, 505 (1959).

83. Treas. Reg. $\$ 1.162-15$ (c) (3) (1959).

84. Payments for the actual purchase of political influence to be cxercised by or upon an administrative agency have, however, been denied deductibility. See Harden Mortgage Loan Co. v. Commissioner, 137 F.2d 282 (10th Cir. 1943) ; Estate of Joseph H. Scobell, 47 B.T.A. 971 (1942) (dictum); text at note 96 infra.

85. See, e.g., N.Y. Times, Jan. 1, 1959, p. 1, col. 2; March 27, 1960, p. 1, col. 4; 104 Cong. Rec. 1934, 1948 (1958); 105 Cong. Rec. 12881-84 (1959) (remartis of Senatcr Dirksen). For an illustration of efforts to influence the executive branch, see $\mathbf{S}$. 
achieve "tax equilibrium" between business and nonbusiness spending would be relatively impotent if it were applicable only at the legislative stage.

Nevertheless, factors against such an extension of the Cammarano policy exist. Perhaps only the legislative process is sufficiently susceptible to pressure activities to warrant the inhibition on the dissemination of information imposed by nondeductibility. When amounts are expended in quasi-judicial hearings, procedural safeguards may raise countervailing policies of the right to counsel and a fair trial ${ }^{80}$ and diminish the possibilities of undue business influence. ${ }^{87}$ Members of administrative and executive agencies are arguably "expert" in the field and have adequate staff assistance and thus are not subject to outside pressures. And in the case of firms subject to ratemaking control the ratemaking body may simply disallow such expenses in calculating rates: indeed, it might be argued that insofar as such expenses are allowed in ratemaking they are tacitly approved and should not be further tampered with by disallowing deductions. ${ }^{88}$

Also, the Cammarano decision may not furnish the basis for a definition of "lobbying" broad enough to encompass activities designed to influence administrative and executive decisionmaking. Unlike the Treasury regulations at issue in Cammarano, the charitable-educational sections, from which the Court argued by analogy, do not include the term "lobbying,"80 and the regulations under those sections are framed so as to exclude activities designed to

Rep. No. 395, 85th Cong., 1st Sess. 37-38 (1957). See also Newman, The Suprcme Court, Congressional Investigations, and Influence Peddling, 33 N.Y.U.L. REv. 796 (1958); Note, 73 Harv. L. Rev. 1178 (1960).

86. These policies argue for the allowance of tax deductions at least to the extent that expenditures are for counsel and for developing material necessary to a full hearing. Sce Brookes, Litigation Expenses and the Income Tax, 12 TAX L. REv. 241 (1957); cf. Waldo Sait, 18 T.C. 182 (1952).

87. In its adjudicative capacity the administrative agency, although its procedures are more relaxed, most nearly resembles a court. See generally Jackson, The Administratiz' Process, 5 J. Social Philosophy 143 (1940). Although pressure groups often resort to the courts, Vose, Litigation as a Form of Pressure Groutp Activity, Annals, Sept. 1958, p. 20, no one has successfully contended that expenditures for such activities should be nondeductible. See Independent Brewing Co., 4 B.T.A. 870 (1926), acq., VI-1 Cum. But.. 3, 8 (1927); George Ringler \& Co., 10 B.T.A. 1134, 1136 (1928). These considerations suggest the possibility of permitting deductibility of expenditures designed to influence administrative proceedings which are quasi-judicial in nature, even if Cammarano were extended to other forms of administrative and executive decision making. While such a distinction may scem plausible, it might be anticipated that the Treasury would have difficulty drawing such a fine line.

88. In Alabama Power Co., 29 P.U.R.3d 209 (FPC 1959), the Federal Power Com. mission held that expenditures by private electric companies for advertising which stated their poor competitive position with respect to publicly owned utilities were not chargeable, for accounting purposes, against the rate payer but were to be borne by the shareholders. The Treasury denied deduction to the same expenditures for income tax purposes. Special Ruling, 6 CCH 1958 Stand. Fed. TAx Rep. $\pi 6352$. Similarly the Commission, in 1957, refused to allow the Tennessee Gas Transmission Co. to pass on legal fees paid after the utility won a rate increase to its customers. N.Y. Times, March 27, 1960, p. 1, col. 2.

89. Int. Rev. Code of 1954, § 501 (c). 
influence administrative and executive decisionmaking. ${ }^{00}$ At least insofar as the decision rested upon a congressional policy reflected in the charitableeducational section, therefore, it would not seem to warrant such an expansive definition of "lobbying." Moreover, one accepted definition is that which the Supreme Court adopted in two decisions ${ }^{91}$ construing the Regulation of Lobbying Act: representations and conmunications made directly to Congress and its members concerning pending or proposed legislation. It is generally assumed that that act does not apply at the administrative-executive stage, 02 and the term would seem to carry a similarly linited meaning in most state regulation-of-lobbying acts. ${ }^{93}$ Although the new regulations also forbid deduction of the expenses of "promotion or defeat of legislation" and state that this term "shall not be limited to the legislative stage,"04 and although this phrase may thus be amenable to a construction which would include the administrative or executive stages, the phrase is supplementary to "lobbying" and may not apply to activity which could not first be termed lobbying. Finally, insofar as the Cammarano decision rested upon reenactment arising from "consistent construction," it could not be viewed as extending to activities directed at administrative and executive bodies since the Treasury has never attempted to apply its regulations in that context..55

But even if the broad policy of Cammarano does not extend to the administrative and executive process, a longstanding line of cases would still deny deductibility to sums expended for the purpose of purchasing infuence to be exercised upon administrative and executive agency personnel. ${ }^{16}$ These cases,

90. "The term 'legislation' ... includes action by the Congress, by any State legislature, by any local council or similar governing body, or by the public in a referendum, initiative, constitutional amendment or similar procedure" Treas. Reg. $\$ 1.501$ (c)(3)-1 (1958). The regulation only prohibits the deduction of expenditures for attempts to influence "legislation."

91. United States v. Harriss, 347 U.S. 612 (1954) ; United States v. Rumely, 345 C.S. 41 (1953). The Cammarano Court suggested that "lobbying" as used in the regulation might be similarly defined. Cammarano v. United States, 355 U.S. 498, 505 n.S (1959).

92. See Zeller, The Federal Regulation of Lobbying Act, 42 Asr. Poi. Scr. REv. 239 (1948); Futor, An Antalysis of the Federal Lobbying Act, 10 FED. B.J. 366 (19-19): Comment, Improzing the Legislative Process: Federal Regulation of Lobbying, 56 YNLE L.J. 304 (1947).

93. See Zeiler, Regulation of Pressure Groups and Lobbyists, Annals, Sept. 1958, p. 94. A few state acts expressly include lobbying before executive agencies. S. REp. No. 395, 85th Cong., 1st Sess. 222 (1957).

94. Treas. Reg. $\$ 1.162-15$ (c) (3) (1959).

95. On the contrary, an early ruling expressly accorded deductibility to such expenses. G.C.M. 1627, VI-1 Cun. Burl. 59 (1927).

96. See, e.g., Harden Mortgage Loan Co. v. Commissioner, 137 F.2d 282 (10th Cir. 1943) ; Rugel v. Commissioner, 127 F.2d 393 (8th Cir. 1942); Alexandria Gravel Co. v. Commissioner, 95 F.2d 615 (5th Cir. 1938) ; Aetna-Standard Eng'r Co., 15 T.C. 284 (1950). Commissioner v. Heininger, 320 U.S. 467, 473-74 (1943), indicated approval of these decisions.

Payments made directly to administrators or executives with the intent of influencing their decision are prohibited by legislation. 18 U.S.C. $\$ \S 201,202$ (1958). Their deductibility would, of course, be denied under Heininger. 
the validity of which has not been seriously questioned, form a much less expansive exception to deductibility than Cammarano since they are specifically limited to cases involving direct payments. ${ }^{07}$ Marking such expenditures for special treatment appears justified by the fact that direct payments of this type have no redeeming virtue; they serve no informational function and substitute monetary incentives for the force of facts and ideas. Other especially opprobrious expenditures for influencing the administrative and executive process, for example, sums spent pursuant to contingent-fee lobbying contracts, could also be brought within this general public policy exception if they are outside the reach of Cammarano.98

\section{Methods of Influence}

Business expenditures for traditional methods of influence-contacting legislators and officials personally-clearly fall within Cammarano. The term "lobbying," which has always appeared in the Treasury regulations, including those considered in Cammarano, normally conjures up the image of buttonholing.

Expenditures incurred in preparing data for and in appearing before legislative or administrative bodies present a more difficult problem because of their more apparent relationship to government's need for information. ${ }^{00}$ When a governmental body entertains testimony in accordance with established procedures, particularly when compulsory process is employed, it is at least arguable that a policy has been expressed in favor of the receipt of information which overrides any policies against deductibility. ${ }^{100}$ Nevertheless, no exception to the Cammarano rationale based upon the need of government for information has been judicially suggested..$^{101}$ In fact, some of the expenditures for which deduction was disallowed in Textile Mills were for testimony before Congress. ${ }^{102}$ The Cammarano decision and the Treasury regulations, as a

97. In resting on broad public policy grounds rather than on a governmentally declared policy, these decisions appear to be an exception to the rule announced in Lilly v. Commissioner, 343 U.S. 90, 97 (1952).

98. See also Harden Mortgage Loan Co. v. Commissioner, 137 F.2d 282, 284 (10th Cir. 1943) (apparently reading Textile Mills narrowly as supporting this line of cases).

99. See Celler, Pressure Groups in Congress, Annals, Sept. 1958, p. 1; H.R. RE1. No. 3138, 81st Cong., 2d Sess. 23-28 (1950) ("The intelligence function of lobbying . . [assumes] special importance in an era of complex and wide-ranging legislation."); 13 CoNc. $Q$. Almanac 734 (1957) (76 members of Congress, 66\% of those polled, state in answer to a questionnaire that most lobbyists are helpful in providing detailed facts on complicated legislative questions).

100. It has been asserted that these expenditures do not substantially differ from those incurred to present arguments before courts. See Note, 67 HARv. L. REv. 1408 (1954); Note, $54 \mathrm{H}_{\mathrm{ARv}}$. L. REv. 852 (1941). But see Sharp, Reflection on the Disallowance of Income Tax Deductions for Lobbying Expenditures, 39 B.U.L. Rev. 365, 385 (1959).

101. Cf. Lucas v. Wofford, 49 F.2d 1027 (5th Cir. 1931) (suggesting distinction between lobbying and appearances to persuade by presentation of facts).

102. Brief for Petitioner, p. 7, Textile Mills Sec. Corp. v. United States, 314 U.S. 326 (1941). 
general proposition, ignore the potentially favorable impact on the political process of more widespread dissemination of information stimulated by the availability of tax deductions.

Business expenditures for political-legislative purposes have, however, been perceptibly refocused in recent decades toward the public generally, or to opinion-forming groups within the public, and away from the actual machinery of government. ${ }^{103}$ In recognition of this development, the regulations before the Court in Cammarano denied deductibility to expenses for "the exploitation of propaganda, including advertising other than trade advertising." Of course, since Cammarano involved statewide referendums in which the sole effective means of influencing the outcome was advertising and publicity directed at the electorate, it might be argued that expenditures for these purposes are nondeductible only in connection with referendums or political campaigns. But it is more likely that such expenditures are nondeductible even when the desired result is the adoption of a bill in Congress or a state legislature. The new Treasury regulations, therefore, explicitly purport to cover expenditures designed to influence members of a legislative body "indirectly, by urging or encouraging the public to contact such members" and also "for carrying on propaganda (including advertising) related to" lobbying or the promotion or defeat of legislation. . $^{104}$

Application of the policy of nondeductibility to these indirect methods of influence raises one of the most difficult post-Cammarano problems: ascertaining whether advertising and propaganda campaigns are sufficiently "related" to a political objective to warrant nondeductibility. The "trade advertising" exception in the Cammarano regulations, reformulated in the new regulations as "institutional or 'good will' advertising,"105 would seem to set forth the principal grounds for denying this necessary connection. Expenses for campaigns which name and promote products without any relationship to political objectives are clearly deductible. But this distinction between promotion of products and of political ideas may in practice be troublesome. For example, the Treasury ruled in 1958 that expenditures by private power companies for publicity asserting their poor competitive position was compared with publicly owned power facilities were nondeductible. ${ }^{100}$ It was the view of the Treasury that the campaign which called for remedial action was in fact designed to affect legislation before Congress. But this ruling is of questionable vitality under the new 1959 regulations which go beyond a "trade advertising" ex-

103. See Celler, supra note 99, at 268; Turner, How Prcssurc Gronps Operate, Annals, Sept. 1958, p. 63, at 68; Note, 11 OHIo ST. L.J. 557 (1950); Comment, 56 YALE L.J. 304, 306-07 (1947) ; H.R. Rep. No. 3138, 81st Cong., 2d Sess. 23, 29 (1950) ("Today, the longrun objective of every significant pressure group in the country is and must incvitably be the creation and control of public opinion ....").

104. Treas. Reg. $\$ 1.162-15$ (c) (1959).

105. Ibid.

106. Special Ruling, 6 CCH 1958 Stand. Fed. TAX Rep. $\llbracket 6352$; see Notc, 46 VA. L. REv. 112, 120-21 (1960). 
ception by stating that deductibility will be allowed for "advertising which presents views on economic, financial, social, or other subjects of a general nature." 107

Assuming that this new regulation constitutes a permissible interpretation of Cammarano, which considered only the "trade advertising" phraseology, the problems which will arise in its administration will be far reaching. A clear distinction between advertising of a "general nature" and that designed to achieve a political-legislative objective would appear impossible to draw with specificity. For example, a 1945 Tax Court decision allowed deductions, over Treasury objections, for a public information program entitled "reselling the American Way to America" carried on by an organization sponsored by the National Association of Manufacturers. ${ }^{108}$ The program provided for the dissemination of information concerning the free enterprise system by radio, motion picture, booklet, outdoor advertising, newspapers, and speakers. Relying upon cases involving World War I expenditures by the Association of Railway Executives for similar purposes, ${ }^{100}$ the Tax Court reasoned that the purpose of the NAM program was to correct unsympathetic public opinion and not, as the Treasury contended, to influence the political process. ${ }^{110}$ No reliable or definite criteria seem to point the way to a decision in cases of this sort. Ostensibly innocuous publicity may in fact be related to unnamed legislation, political parties, or candidates and may create a climate in which the defeat or adoption of a legislative bill or the success or failure of a candidate or party is much affected. ${ }^{111}$ Whether this type of expenditure, which may well account for the bulk of politically-related business activity, is to be disallowed in individual cases will necessarily depend upon how far the Treasury and the courts wish to carry the Cammarano rationale. That rationale could be limited drastically by placing most questionable propaganda in the category of "good will advertising" or social and economic publicity of a "general nature."

The regulations seem properly to envision a test of purpose rather than effect in denying deductibility. Thus, if the propaganda is designed to influence the political process, even if its impact is either speculative or clearly negative

107. Treas. Reg. \& 1.162-15(c) (1) (1959).

108. Addressograph-Multigraph Corp., 4 CCH Tax Ct. Mem. 147 (1945). The Comnissioner had disallowed the deductions on the grounds that the payments constituted contributions to a charitable-educational organization which was engaging in a substantial amount of legislative activity.

109. Texas \& Pac. Ry. v. United States, 72 Ct. Cl. 629, 52 F.2d 1040 (1931); Kansas City So. Ry., 22 B.T.A. 949, 963 (1931) ; Norfolk So. R.R., 22 B.T.A. 302 (1931), rev'd on other groutds, 63 F.2d 304 (4th Cir. 1933); Missouri Pac. R.R., 22 B.T.A. 267 (1931); 1.m Angeles \& S.L.R.R., 18 B.T.A. 168 (1929).

110. $4 \mathrm{CCH}$ Tax Ct. Mem. at 180-81.

111. See H.R. Rep. No. 3138, 81st Cong., 2d Sess. (1950) ; Bicks \& Fricdman, Ricyulation of Federal Election Finance: A Case of Misguided Morality, 28 N.Y.U.L. Rev. 975, 995 n.97 (1953); Hearings Before the House Select Committee on Lobbying Activitics, 81st Cong., 2d Sess., pt. 5, at 146-48 (1950). News releases may also be used, see id. at 71, 95, and access to editorial columus may be sought, see H.R. REP. No. 3138, op. cit. supra at 37. 
to the taxpayer's objective, expenditures for it would be disallowed. For example, if no bill is actually pending during the taxable year for which deduction is claimed, it might be argued that the Cammaramo rule of nondeductibility is inapplicable because the expenditure is not "related to" the promotion or defeat of legislation. But such a mechanical distinction would not be proper. Massive lobbying may be mounted long before the bill in question is actually introduced, and one objective of the campaign may be to prevent introduction from taking place. Cammarano would not seem to require that the citadel be successfully stormed before expenditures for getting there become disallowable. On the other hand, purpose should not be taken to require a finding of subjective intent, which should be viewed as irrelevant. So long as the propaganda seems reasonably related to a political-legislative objective, as measured by all the circumstances including the wording of the media selected, it should fall within the rule of Cammarano.

\section{Organizational Structure of the Influcncing Agency}

\section{Ad Hoc Multienterprisc Activities}

Of the organizational structures which businesses may adopt through which to channel expenditures for the influencing of governmental policy, perhaps the most obvious is that employed in Cammarano and Stratuss. In those cases, a number of independent enterprises sharing the same legislative objective set up an ad hoc body with the limited purpose of seeking that objective. ${ }^{112} \mathrm{By}$ thus concerting their activities, businesses may eliminate duplication and conflict, hire a specialized staff-or, as in Textile Mills, enter into a contract with an outside lobbying or public relations firm-and, in general, obtain more efficient results for their lobbying dollars. ${ }^{113}$ They may also be able to obtain considerable anonymity behind the front of the ad hoc body, which may successfully display a public facade of financial disinterest and nonpartisanship. ${ }^{114}$

112. Although the decisions are by no means clear, it appears that contributions to ad hoc organizations were, prior to Canmarano, denied deductibility in a few instances. See, e.g., Old Misson Portland Cement Co. v. Commissioner, 69 F.2d 676 (9th Cir. 1934) ; The Mosby Hotel Co., 23 P-H Tax Ct. Mem. 920 (1954); H. R. Cullen, 41 B.T.A. 1054 (1940); The Adler Co., 10 B.T.A. 849 (1928).

113. A recent illustration of such concerted activity is the natural gas industry's formation of the General Gas Committee subsequent to Phillips Petroleum Co. v. Wisconsin, 347 U.S. 672 (1954), which held that natural gas production was subject to regulation by the Federal Power Commission. The committee was formed for the sole purpose of securing legislation to exempt the production of natural gas from such regulation. Contributions to it, some of which were deducted as business expenses, totalled $\$ 118,625$. The effort was important in the passage of the Harriss-Fulbright Bill which, however, was vetoed by the President. S. ReP. No. 395, 85th Cong., 1st Sess. 9 (1957). The Natural Gas Bureau Bill, H.R. 6645, 85th Cong., 2d Sess. (1957), was also vetoed. 102 Coxc. REc. 14651 (1956). The industry's efforts in connection with this bill were investigated fully: S. Rep. No. 1724, 84th Cong., 2d Sess. (1956).

114. See Comment, 56 Y YLE L.J. 304, 311-13 (1947) (outlining the methods adopted by public utility companies in their campaign against government regulation or ownership). S. Rep. No. 395, 85th Cong., 1st Sess. 9-33 (1957). 
Furthermore, the limited objectives of such groups, on which widesprend agreement is possible, enable a maximum number of enterprises to contribute, perhaps resulting in panticipation transcending the normal lines of industry cooperation. And by limiting the existence of the structure to the period during which the desired measure is pending, ${ }^{115}$ the necessity of accumulating funds can be avoided and any excess of income over expenditures can be returned to contributors. Hence, no necessity for paying an income tax or for seeking an exemption will normally arise. ${ }^{116}$

But this device would be obviously susceptible to Cammarano. So long as the activities of the body are "related to" a political-legislative goal, contributions to them will be wholly nondeductible. Since their objectives will normally be unambiguous, identification of the contributions to ad hoc groups as nondeductible will be relatively easy, and the administration of the Cammarano rule will raise a minimum of difficulties.

In addition, by extending the Cammarano rationale a bit further, the Treasury could seek to make all the ad hoc body's expenditures nondeductible and require it to report all contributions as income. ${ }^{117}$ Although no attempt was apparently made to disallow expenditures of the groups in Cammarano and Strauss, Textile Mills, broadly read, would seem authority for denying deductibility to their expenditures and taxing their income. ${ }^{118}$ Incleed, carried to its logical extreme, the Cammarano policy could lead to a long chain of nondeductibility. Suppose that a Canmarano-type ad hoc body hired a public relations firm which in turn hired a lobbying firm which retained a lawyer. The Treasury might attempt to deny deductions not only to the contributions of the enterprises to the ad hoc body but also to the expenditures of that body for the public relations firm, to the expenditures of the public relations firm for the lobbying firm, to the expenditures of the lobbying firm for the lawyer, and to the expenses of the lawyer. ${ }^{119}$

In all probability, however, few would argue for nondeductibility of such expenses, at least when the initial contributions to the ad hoc body have al-

115. Lenhart \& Schriftgiesser, Management in Politics, Annals, Sept. 1958, p. 32, at 37.

116. Although these organizations might appear to be encompassed by INT. REv. Cov: of 1954, $\S 501$ (c) (6) and thus to be entitled to tax exemption as business leagues, sce the definition in Treas. Reg. $\$ 1.501$ (c) (6) -1 , they are not accorded such status, sec Rev. Rul. 54-442, 1954-2 CuM. Bul. 131. Arkansas Legal Control Associates Inc., contributions to which were involved in Stranss, applied for such an exception and was rejected. Brief for Respondents, p. 7 n.3, Cammarano v. United States, 358 U.S. 498 (1959).

117. The expenditures of the Cammarano trust fund were for the promotion of legislation just as much as were the contributions to it. Record, pp. 103-07, Cammarano v. United States.

118. Textile Mills involved the expenditures of a third-party organization which, if the contingent fee arrangement is disregarded, is distinguishable from the Cammarano ad hoc body only because of its profit motive. See Joseph Schoenbaum, $16 \mathrm{CCFI}$ Tax Ct. Mcm. 615 (1957) (expenses of lawyer retained, not on contingent fee basis, to examine possibility of obtaining state legislation to legalize racing).

119. Cf. Spofford, The Impact of Some Recent Devclopments in Tax Litigation and Legislation, 37 Taxes 1068, 1070 (1959). 
ready been disallowed on the returns of the contributing enterprises. This conclusion appears to follow from a decision handed down shortly before Cammarano. In Commissioner $v$. Sullivan ${ }^{120}$ the Court answered in the affirmative the question of "whether amounts expended to lease premises and hire employees for the conduct of alleged illegal gambling enterprises . . . [were] deductible as ordinary and necessary business expenses . . . ."121 If expenses of an illegal organization are deductible, it would seem that the legal and presumably less objectionable expenses of lobbying organizations would be also. The Sullivan Court did carve out an exception to its general rule, stating that expenses for "certain condemned activities" are still nondeductible. Although it cited Textile Mills as an example of this exception, ${ }^{122}$ that citation presumably refers to the contingent-fee contract there involved, ${ }^{123}$ and the exception to Sullivan would not seem to extend to other forms of political-legislative activities. Furthermore, a denial of deductibility to the expenditures of such ad hoc bodies would go far beyond the view expressed in Sullivan that the gross receipts of a business should not be taxed unless Congress specifically states that it is to be done, ${ }^{124}$ and would involve the Treasury in endless enforcement problems.

\section{Exempt Charitable-Educational Organizations}

In addition to employing ad hoc Cammarano-type organizations, businessmen, either in concent with others or alone, may seek to effectuate the legislative aims of their businesses through charitable-educational organizations accorded exempt status under section 501(c)3.125 This status carries with it the privileges of making "reasonable" accumulations in the organization free from tax liability ${ }^{126}$ and from obligation to file income tax returns. ${ }^{127}$ And under section $170(\mathrm{~b})$ contributions to such organizations may be deducted by individual businessmen in an amount not exceeding twenty per cent of their gross income and by corporations in an amount not exceeding five per cent

120. 356 U.S. 27 (1958).

121. Ibid.

122. Id. at 28 .

123. Only the contingent-fee arrangement was in any way "condemned" by the Tcrtils IIills Court. Textile Mills Sec. Corp. v. Commissioner, 314 U.S. 326,338 (1941) ("contracts to spread such insidious influences through legislative halls have long been condemned"). Certainly lobbying in general is not "condemned." See Celler, Pressure Grouts in Congress, Annals, Sept. 1958, p.1.

124. 356 U.S. at 28.

125. INT. REv. CODE of 1954, $\$ 501$ (c) (3) (encompassing corporations, funds, foundations and community chests). For a discussion of the Internal Revenue Service's administration of this section see Hearings on H.R. Res. 561 Before the House Select Committee To Inzestigate Tax-Exempt Foundations and Comparable Organisations, S2d Cong., 21 Sess. 56 (1953) (testimony of Norman A. Sugarman, then Assistant Commissioner of Internal Revenue).

126. INT. Rev. CoDE of 1954, § 504.

127. These organizations must, however, file annual informational returns. Isv. REx. CODE of 1954, § 6033. 
of their gross income. ${ }^{128}$ In addition to furnishing a possibility of disguising "business expenses" nondeductible under Cammarano as deductible "charitable contributions," the charitable-educational organization may offer a greater aura of respectability and may afford greater anonymity than alternative outlets for political-legislative expenditures. The official grant of exemption may operate as a stamp of legitimacy and avoid questions as to sponsorship and charges of partisanship which might diminish the effectiveness of Cammaranotype organizations.

But 501(c)3 and the applicable regulations seek to impose rigid restrictions on the pursuit of political objectives by charitable-educational organizations. A claim for 501 (c) 3 exemption must meet two statutory tests. First, the organization must be "organized and operated exclusively" for "charitable . . . or educational purposes" and, second, "no substantial part" of its activities in pursuing this exclusive purpose may consist of "carrying on propaganda or otherwise attempting to influence legislation" or supporting or opposing candidates in "any political campaign."129

Within the broad confines of the term "educational," business-supported organizations may be able through widespread dissemination of publications and use of other mass media to create a more favorable climate of public opinion for specific legislative or political objectives. ${ }^{130}$ An example is the Foundation for Economic Education, sustained by large corporate contribu-

128. INT. REv. CODE of 1954, § 170(b).

129. INT. REv. CoDE of 1954, $\$ 501$ (c)3. These restrictions on the activitics of charitableeducational organizations have been extensively discussed. See Latcham, Priz'alc Charitable Fonndations: Some Tax and Policy Implications, 98 U. PA. L. Rev. 617 (1950): Note, 57 Colum. L. Rev. 271 (1957); Note, 37 VA. L. Rev. 988 (1951); Note, 1956 WIs. L. REv. 165. The idea that these organizations have a duty to participate in controversial areas which might be labeled "political," a duty which can not be fulfilled under the present tax laws, has also been expressed. See Embree, Timid Billions: Arc the Foundations Doing Their Jobs?, Harper's, March 1949, p. 28; Devine, Pioneers or Propagandists, 29 SURvey Graphic 348 (1940).

This restriction was orginally formulated by the courts, see Slee v. Commissioner, 42 F.2d 184 (2d Cir. 1930); Weyl v. Commissioner, 48 F.2d 811 (2d Cir. 1931), and was initially enacted into the Revenue Act of $1934, \S 101(6)$. The legislative history is meager. 78 CoNG. Rec. 5861, 5959, 7831 (1934). It has been suggested that this statutory proscription adds nothing to the common law. Reiling, Federal Taxation: What is a Charitable Organization?, 44 A.B.A.J. 525 (1958); see In re Murphy's Estate, 7 Cal. 2d 712, 62 P.2d 374 (1936); Collier v. Lindley, 203 Cal. 641, 266 Pac. 526 (1928); Bowditch v. Attorncy General, 241 Mass. 168, 134 N.E. 796 (1922). See generally Note, 37 VA. L. REv. 988 (1951).

130. It is obviously difficult to distinguish between education and propaganda for a proscribed purpose. See Sugarman, Current Issues on the Use of Ta.r-ExEmpt Organizations, 34 Taxes 795 (1956) ; Young \& Galvin, Proposed Regulations Do Not Clarify Ta.t Status of "Exempt Organizations," 5 J. Taxation 298 (1956); Note, 42 A.B.A.J. 773 (1956). See also Weyl v. Commissioner, 48 F.2d 811 (2d Cir. 1931); Cochran v. Com* missioner, 78 F.2d 176 (4th Cir. 1935) ; Seasongood v. Commissioner, 227 F.2d 907 (6th Cir. 1955); Hearings Before the Special Committee To Investigate Tax-Excmpt Foundations and Comparable Organizations, 83rd Cong., 2d Sess., pt. 1, at 429 (1954). 
tions, ${ }^{131}$ which obtained 501 (c) 3 status ${ }^{132}$ for its program of educating the public in the disadvantages of governmental intervention in the economy. Under the 1959 regulations, such organizations do not lose the "exclusively educational" character even if their pronouncements advocate "a particular position or viewpoint so long as it presents a sufficiently full and fair exposition of the pertinent facts as to permit an individual or the public to form an independent opinion or conclusion."133 The meaning of the latter limitation is perhaps illustrated by denial of exempt status to the Committee for Constitutional Government ${ }^{134}$ which appears distinguishable from the Foundation for Economic Education only in the greater militancy of its views. ${ }^{138}$

One limitation on the availability of this device is implied by the term "educational" itself: activity immediately identifiable as advocacy of the pros or cons of legislation or political candidates will be viewed as not "exclusively" educational."136 For example, exemption as an educational organization was denied the Natural Gas and Oil Resources Committee, ${ }^{137}$ and deduction of some two million dollars in contributions to the committee by firms in the natural gas industry was therefore disallowed.138 The committee's stated purpose was to educate the public on the "benefits of an unregulated industry" and to engage solely in conducting an information and education program, ${ }^{130}$ but its apparent connection with industry attempts to promote the HarrissFulbright Bill probably accounted for denial of 501 (c) 3 exemption. In general, however, the outer boundaries of "exclusively educational" remain necessarily obscure and dependent upon a case-by-case evaluation. ${ }^{140}$ Indeed, the regulations, which set forth such criteria as whether the organization's activities are

131. Large contributors include E. I. duPont de Nemours, Chrysler Corp., Gulf Oil Co., Marshall Field \& Co., and Montgomery Ward Co. Hearings Before the House Select Committee on Lobbying Activities, 81st Cong., 2d Sess., pt. 8, at 14-20 (1950).

132. Tax exemption was granted on April 2, 1947. H.R. REp. No. 3138, 81st Cong., $2 d$ Sess. 20 (1950).

133. Treas. Reg. § 1.501 (c) (3)-1(d) (3) (1958).

134. Hearings Before the House Select Committee on Lobbying Actizities, 81st Cong., 2d Sess., pt. 5, at 39-40 (1950).

135. The only difference between the two organizations appears to be that the foundation's "literature contains little of the specific exhortation to action which is so much a part of the publications distributed by the Committee..." H.R. REP. No. 3138, 81st Cong., 2d Sess. 33 (1950).

136. Cf. Weyl v. Commissioner, 48 F.2d 811 (2d Cir. 1931).

137. S. Rep. No. 395, 85th Cong., 1st Sess. 17 (1957).

138. Id. at 13 .

139. Id. at 11.

140. The courts have regarded the charitable exemptions as liberalizations in favor of the taxpayer which are not to be narrowly construed. Helvering v. Bliss, 293 U.S. 144 (1934). The Treasury's initial attempts restrictively to define the term "educational" therefore met with little success, and this liberal approach requires the drawing of fine lines on the basis of all the facts presented. Hearings Before the Special Commillec To Investigate Tax-Exempt Foundations and Comparable Organizations, $83 \mathrm{~d}$ Cong., $2 \mathrm{~d}$ Sess., pt. 1, at 428-34 (1954). 
"beneficial to the community,"141 would seem to invite subjective evaluation on the basis of the predilections of the Treasury and courts. ${ }^{142}$

Organizations which meet this "exclusively educational" test may devote an insubstantial portion of their resources to political activities and still satisfy 501 (c) 3's second test. But unless such activities are reasonably ancillary to the organization's exempt purpose, that purpose will lose its "exclusive" character and exemption should be denied. ${ }^{143}$ Thus, for example, if several corporations set up a charitable foundation to provide scholarships for the children of employees, an attempt to influence natural gas legislation would not be reasonably ancillary to the organization's purpose and would result in loss of 501 (c) 3 exemption, even if such attempt formed only an insubstantial portion of the organization's activities. ${ }^{144}$ On the other hand, the Foundation for Economic Education might, as an insubstantial portion of its overall program, attempt to influence natural gas legislation since such attempts would not seem to run counter to its exclusive purpose. Nonetheless, such organizations must be wary lest even an insubstantial program of actively influencing legislation be taken to negate their "educational" purpose; such a program is in danger of coloring the activities of the entire organization and may well be held sufficient evidence that the organization's clominant purpose is political.

Businessmen may also be able to make deductible contributions for political purposes to existing 501 (c) 3 organizations which happen to share with them a common political objective. For example, the Daughters of the American Revolution is an exempt 501(c)3 organization ${ }^{145}$ whose political-legislative activities have been deemed to be insubstantial. Thus, within the limits of insubstantiality, the Daughters may attempt to influence the outcome of particular legislation, and businessmen whose businesses would be benefited by the Daughters' view on this legislation could make deductible contributions to the

141. Treas. Reg. $\$ 1.501$ (c) (3)-1(d) (3) (1959).

142. The statute "provides much leeway for varied opinions in a field in which persons are likely to have strong personal views." Hearings, supra note 140 , at 431 . Subjcctive evaluation seems to have been the rule in the past. See, e.g., Girard Trust Co. v. Commissioner, 122 F.2d 108 (3d Cir. 1941) ; Liberty Nat'l Bank \& Trust Co. v. United States, 122 F. Supp. 759 (W.D. Ky. 1954) ; Old Colony Trust Co. v. Welch, 25 F. Supp. 45 (1). Mass. 1938).

143. See Slee v. Commissioner, 42 F.2d 184 (2d Cir. 1930); Martha Hubbard Davis, 22 T.C. 1091 (1954); Huntington Nat'1 Bank, 13 T.C. 760 (1949). The substantiality standard of the second test has on occasion seemingly been confused with the exclusivity standard of the first. See Vanderbilt v. Commissioner, 93 F.2d 360 (1st Cir. 1937): Liberty Nat'l Bank \& Trust Co. v. United States, 122 F. Supp. 759 (W.D. Ky. 1954).

144. On the same basis, a corporate foundation formed to funnel corporate fund to other 501 (c) 3 organizations which made minor contributions to a nonexempt presstre group might have its exempt status challenged. Such nonoperating foundations ars undoubtedly common due to the tax advantages which inhere in them. See $3 \mathrm{CCH} 1960$ Stand. Fed. Tax Rep. If $3033.023-0249$.

145. I.T. 2334, VI-1 Cum. Burl 82 (1927). See also Genevieve Tucker, 2 B.T.A. 796 (1925). 
Daughters which could then expend some of the contributions for politicallegislative activities.

A difficult problem raised by these various possibilities is the interpretation of substantiality. This test was first introduced in $1934^{140}$ and, instead of clarifying the statute, has led to considerable conflict in the decisions ${ }^{147}$ and has not diminished the apparent reliance of the Treasury and the courts on shifting criteria which seem primarily to reflect agreement or disagreement with the goals of the activity in question. ${ }^{148}$ And the new regulations issued by the Treasury in 1959, which set forth more detailed interpretations of substantiality, ${ }^{149}$ do not seem to offer much hope for more definite standards. ${ }^{100}$ The regulations would deny exemption, without further inquiry, to organizations whose articles "expressly empower" them to carry on political activities as defined in 501 (c) 3 otherwise than insubstantially..$^{151}$ But this provision is readily avoided by a method expressly authorized in the regulations: inserting in the organizational papers a statement, phrased in the terms of the statute, that no substantial part of the organization's activities can be political as defined in 501 (c) $3 .^{152}$ The regulations also provide that an "action organization" will not satisfy the substantiality test. An organization will be deemed to fall within this class if its primary objective may be attained only through legislative change which the organization campaigns for, or advocates, or if a substantial part of its activities consist either of contacting or urging the public to contact members of a legislative body for the purpose of promoting legislative change or advocating the adoption or rejection of legislation or of supporting or opposing candidates in any political campaign. ${ }^{163}$ But this "action organization" definition seems to add little if anything to the terms of the statute as interpreted by prior regulations and case law. ${ }^{15 \pm}$ And neither the

146. Revenue Act of 1934, ch. 277, § 101(6), 48 Stat. 700. The Treasury had previously promulgated similar standards in a regulation issued under the 1926 act. Treas. Reg. 80 (1934). The legislative history with respect to this addition is meager, but it appears that Congress' desire was to deny deductibility to selfishly motivated contributions. 78 CoNG. Rec. 5861, 5959, 7831 (1934).

147. Sharp, Reflection on the Disallowance of Income Tax Deductions for Loblying Expenditures, 39 B.U.L. REv. 365, $387 \mathrm{nn} .131$ \& 132 (1959).

148. See League of Women Voters v. Commissioner, No. 232-56, Ct. Cl., January 20, 1960; Liberty Nat'l Bank \& Trust Co. v. United States, 122 F. Supp. 759 (IV.D. Ken. 1954) ; Henriette T. Noyes, 31 B.T.A. 121 (1934) (all involving the League of Women Voters). See generally Hearings, sipra note 140, at 429-34.

149. Treas. Reg. $\$ 1.501$ (c) (3)-1, adopted June 26, 1959, by T.D. 6391.

150. But see Sharp, Reflection on the Disalloz'asse of Income Tox Deductions for Lobbying Expenditures, 39 B.U.L. REv. 363, 389 (1959) ("the new regulations slwuld be more of an aid in construing the statutory provision").

151. This is the so-called "organizational test" which also provides that the purposes must be limited to one or more exempt purposes. Treas. Reg. $\$ 1.501$ (c) (3)-1 (b) (1959).

152. Treas. Reg. $\S 1.505$ (c) (3)-1(b) (ii) (1959).

153. Treas. Reg. $\$ 1.501$ (c) (3)-1(c) (1959).

154. See Mfarshall v. Commissioner, 147 F.2d 75 (2d Cir. 1945) (recipient could effectively accomplish its aims only through legislative change); Leubuscher v. Com- 
regulations nor the case law seem to afford any answer to the crucial question of whether substantiality turns upon absolute dollar amounts expended or upon the percentage of total expenditures or both. ${ }^{165}$

Assuming that the substantiality test is met, all contributions to the exempt organization will be deductible. Although the broad language of Cammarano might seem to require that such contributions be denied deductibility in proportion to the organization's political activity, such an application of the Cammarano policy would appear impossible without an amendment to the Code. Contributions to 501 (c) 3 organizations are governed by the all-ornothing provisions of section 170 (c), not by section 162 (b), the unique terms of which-"ordinary and necessary"-are viewed by the Treasury as sufficiently ambiguous to warrant partial denial of deductibility of contributions to business leagues. ${ }^{156}$ Furthermore, partial denial of deductibility to contributions to 501 (c) 3 organizations wotld likely force such organizations to abandon even their insubstantial political activities, and, therefore, indirectly repeal 501 (c) 3's sanction to such activities. On the other hand, a recent revenue ruling may offer an alternative means in some instances of achieving a nearequivalent implementation of the Cammarano policy. By a rigid application of the substantiality test, the Treasury could deny 501 (c) 3 exemptions. Under the revenue ruling, organizations denied exemption for this reason may be subsequently granted such exemption by splitting off their political activities and placing them in a separate stbsidiary. ${ }^{167}$ Contributions to the subsidiary would thus be nondeductible and contributions to the exempt parent deductible, the same result as if the original organization had been granted exemption and contributions denied deductibility in proportion to its political-legislative activities.

It might also be argued that a logical extension of Cammarano and Te.tille Mills requires that 501 (c) 3 organizations be taxed-the equivalent of denying deductibility to their expenses-on sums, even though insubstantial, expended for political-legislative activity. But this argument flies directly in the face of 501 (c)3's total exemption of organizations which meet its two tests. Only a very broad reading of Cammarano would warrant such a result and, since the "sharply defined" policy of which the Cammarano Court speaks was based in part upon analogy to 501(c)3, it would seem impossible for Cammarano to override express language of that section. Furthermore, since con-

missioner, $54 \mathrm{~F} .2 \mathrm{~d} 998$ (2d Cir. 1932) (the purpose of the recipient was to effect legislative change through advocacy); James J. Forstall, 29 B.T.A. 428 (1933) (purpose of recipient was to effect change in governmental methods of dealing with international questions).

155. See Sharp, supra note 150 , at $386-90$.

156. Treas. Reg. § $1.162-15$ (c) (2) (1959). Proportionate disallowance was initiated in 1954. Rev. Rul. 54-442, 1954-2 Cum. Bull. 131.

157. Rev. Rul. 54-243, 1954-1 Cum. Butc. 92. The Committee for Constitutional Government, which was denied a tax-exemption, see note 134 supra, formed America's Futurc Inc. as a subsidiary, operated from the same address, which was accorded tax-exempt status. H.R. REP. No. 3138, 81st Cong., 2d Sess. 17 (1950). 
tributions to 501 (c) 3 organizations might be properly characterized as "gifts," taxing them even in part to the organization would appear inappropriate in light of the Code's exclusion of gifts from the gross income of the recipient. ${ }^{159}$

In sum, although charitable-educational organizations may offer some advantages to business spending in the political arena not afforded by alternative structures, 501(c)3 provides a relatively restrictive framework within which to operate in the political arena. While a vigorous interpretation of that section against businessmen using such organizations to promote the political-legislative ends of their businesses might seem justified, such an interpretation must also take into account others who would be affected. Since exempt charitableeducational organizations afford the sole deductible means by which comparable nonbusiness activities may be carried on, a more relaxed interpretation of 501 (c) 3 may therefore be preferable. ${ }^{159}$

\section{Exempt Business Leagues}

The organizations most actively engaged in expressing business' views on political issues and in seeking to effectuate their legislative aims are longstanding business leagues ${ }^{160}$ which are generally speaking one of two types. The first is the "trade association," composed of firms in the same industry, which concerns itself with the industry's problems, conducting research, gathering statistics and disseminating the sesults through conferences, conventions, and printed material.161 It also formulates or helps to formulate industryvide political-legislative policies which it communicates to legislators and the public, thereby providing "one of the major means by which business management gets its policies across to government."162 A primary example of this type of organization is the National Association of Real Estate Boards, which represents 60,000 realtors; in filing under the Regulation of Lobbying Act, this

158. INT. REv. CODE OF 1954, \$ 102.

159. Some would argue that the restrictions even as loosely interpreted hinder the desirable activities of charitiable-educational organizations far too much. See Devine, Pioneers or Propagandists?, 29 SuRvey Graphic 348 (1940).

160. Blaisdelz, Amsericax Dearocracy under Pressure 62 (1957); Lenhart \& Schriftgiesser, Management in Politics, Annals, Sept. 1958, p. 32; Comment, 56 Y YLE L.J. 304, 322 (1947). See also H.R. Rep. No. 3239, 81st Cong., 2d Sess. 25 (1951). See the list of organizations reporting the largest amount spent under the Federal Regulation of Lobbying Act in 1958, 15 Cong. Q. Aluranac 678 (1959), in 1957, 14 Cong. Q. Alssa:ace 627 (1958).

161. See 1 TRAdE REG. Rep. \ 2017 (1954); Lenhart \& Schriftgiesser, Manayemen in Politics, Annals, Sept. 1958, p. 32, at 36.

162. Id. at 37. For examples of politically active trade associations and their methods, see S. REP. No. 395, 85th Cong., 1st Sess. 34-36 (1957). For the specified legislative aims of some of these organizations in 1960, see 15 Cong. Q. Alaranac 677 (1959) (Transportation Associations). Contributions to these organizations are not affected by the Federal Corrupt Practices Act and their activities may well benefit candidates. Bicks \& Friedman, Regulation of Federal Election Finance: $A$ Case of Misguided Miorality, 23 N.Y.U.L. Rr. 975, 995 (1953). 
organization acknowledged spending 65,301 dollars in 1958 for direct lobbying before Congress. ${ }^{163}$ The second type of business league has membership transcending any particular industry lines and concerns itself with the broader areas in which business has an interest. ${ }^{104}$ Such organizations engage in research in these areas and present views on broad problems to the public and to various legislatures. Perhaps the best examples of this class are the National Association of Manufacturers and the United States Chamber of Commerce. ${ }^{108}$ In 1950 the former reported that it expended 84,710 dollars for direct lobbying before Congress and 2,000,000 dollars for the education of the public.100

Section 501(c) 6 of the Internal Revenue Code, in conjunction with section 501(a), accords tax-exempt status, permitting tax-free accumulations and freedom from the filing of income tax returns, to:

Business leagues, chambers of commerce, real-estate boards or boards of trade not organized for profit and no part of the net earnings of which inures to the benefit of any private shareholder or individual.107

In contrast to section 501(c)3, this section imposes no restrictions on the political-legislative activities of organizations comprehended within its exemption. Moreover, the deductibility of any payments made by business to exempt business leagues is controlled only by the "ordinary and necessary" wording of section 162, which imposes no limits on the percentage of an individual or corporate taxpayer's gross income which the taxpayer may deduct as contributions to such organizations, if "ordinary and necessary."108 Under its new regulations, however, the Treasury has viewed Cammarano as rendering contributions to 501 (c) 6 organizations which engage in a substantial amount of legislative activity nondeductible, except to the extent that the taxpayer "clear-

163. 15 Cong. Q. Almanac 680 (1959). This body is one of the best organized for legislative activity. H.R. REP. No. 3138, 81st Cong., 2d Sess. 24-26 (1950). For examples of one lobbying method utilized by this and other trade associations, see id. at 37-40 (instances of so-called editorial advertising). The amounts which these organizations acknowledged spending for "lobbying" during 1957 and 1958 may be found in 14 Cong. Q. Almanac 627 (1958) and 15 Cong. Q. Almanac 678 (1959).

164. Lenhart \& Schriftgiesser, stipra note 162, at 37. See also Smith-Bridgman \& Co., 16 T.C. 287 (1951) ; Addressograph-Multigraph Corp., 4 CCH Tax Ct. Mem. 147, 181-82 (1945).

165. Lenhart \& Schriftgiesser, supra note 165 , at 37; Blaisdell, supra note 161 , at 62 ; see S. REP. No. 395, op. cit. sulpra note 163, at 42 . For their legislative achicvements in 1959 and their goals for 1960 see 15 Cong. Q. Almanac 674 (1959).

166. H.R. REp. No. 3138, 81st Cong., 1st Sess. 5, 6.

Considerations outlined in this section as applying to business leagues and trade associations are also applicable to labor and farm organizations, which are similarly exempt from taxation, similarly active politically, and contributions to which are similarly deductible only as business expenses. See note 26 supra.

167. INT. REv. CODE OF 1954, § 501 (c) 6 .

168. See, e.g., Smith-Bridgman \& Co., 16 T.C. 287 (1951); Emery, Bird, Thayer Dry Goods Co., 20 B.T.A. 796 (1930); Hirsch-Weis Mfg. Co., 14 B.T.A. 796 (1928). The amount deductible as a charitable contribution is limited to a percentage of gross income. INT. REv. CODE OF 1954, \& 170(b). 
ly" shows that such contributions are not expended for legislative activity. ${ }^{160}$ For purposes of discussion, it will be helpful to test these regulations first as applied to special assessments and contributions for political-legislative activities and, second, as applied to regular dues payments.

Although prior to Textile Mills the Treasury was unsuccessful in denying deduction to special assessments and contributions, ${ }^{170}$ the lower courts have upheld its denials since that case. ${ }^{171}$ And the expenditures involved in Cammarano itself were, practically speaking, payments made to a tax-exempt trade association specifically for legislative activity. ${ }^{172}$ With respect to these payments, therefore, construction has been consistent in favor of denial, and Cammarano would require nondeductibility. Thus, the new regulations properly conclude that "in no event shall special assessments or similar payments (including an increase in dues) made to any organization for any" legislativepolitical purpose be deductible. 173

With respect to regular dues payments, the regulations' rule of disallowance is of dubious validity. The "consistent construction" which partially justified use of the reenactment doctrine in Cammarano is to the contrary with respect to such contributions. Apparently, they have been disallowed only once ${ }^{174}$ when the "ordinary and necessary" criteria were otherwise satisfied. ${ }^{175}$

169. Dues and other payments to an organization, such as a labor union or a trade association, which otherwise meet the requirements of the regulations under section 162 , are deductible in full unless a substantial part of the organization's activities consists of one or more ... [proscribed legislative activity]. If a substantial part of the activities of the organization consists of one or more of those so specified, deduction will be allowed only for such portion of such dues and other payment, as the taxpayer can clearly establish is attributable to activities other than thuse so specified.

Treas. Reg. § 1.162-15(c) (2) (1959).

170. See, e.g., Texas \& Pac. Ry. v. United States, 72 Ct. Cl. 629, 52 F.2d 1040 (1931); Best Brewery Co., 16 B.T.A. 1354 (1929); George Ringler \& Co., 10 B.T.A. 1134 (1928).

171. See, e.g., Míosby Hotel Co., 23 P-H Tax Ct. Miem. 920 (1954); MfeClintuchTrunkey Co., 19 T.C. 297 (1952). But the courts have disagreed with the Commissioner on whether the particular payments were for proscribed purposes. Smith-Bridgman Co., 16 T.C. 287 (1951) ; Addressograph-Muitigraph Corp., 4 CCH Tax Ct. Mfem. 147, 181 (1945).

172. In Cammarano the contributions were paid to a trust fund formed by the Washington Beer Wholesalers Ass'n, 358 U.S. at 500 (1959), which was a tax-excmpt trade association, Record, p. 22, Cammarano v. United States, 358 U.S. 498 (1959).

173. Treas. Reg. $\$ 1.162-15$ (c) (2) (1959).

174. McClintock-Trunkey Co., 19 T.C. 297 (1952).

175. Although the decisions do not expressly distinguish between assessments and ordinary dues, because all litigated contributions were, according to the decisions, made for a specific purpose, it is probable that they were special assessments. See case cited note 172 supra. But see Spiegel, Deductibility of Lobbying, Initiatize, and Refcrendum E.rpenses: A Problem for Congressional Consideration, 45 CALIF. L. REv. 1, 19 (1957) (due. have been denied deduction "where the association was operated 'primarily' for legislative purposes."). See also Sharp, Reflection on the Disallowance of Income Tax Deductions for Lobbying Expenditures, 39 B.U.L. REv. 365, 382 (1959). 
Furthermore, the apparent congressional decision not to condition the taxexempt status of business leagues on the amount of their political-legislative activities precludes the discovery of a "sharply defined" policy requiring disallowance by analogy to section 501 (c)3. Moreover, to the extent that this omission indicates congressional approval of the normal lobbying activities of business leagues, disallowance would undercut that approval by impairing receipt of dues for such activities. ${ }^{176}$ To the extent that disallowance would cause the organization to reduce or eliminate its regular political-legislative activities, the regulation would introduce a limitation into the tax laws which Congress omitted. Cammarano should not be read to go that far..$^{177}$

By providing, for no expressed reason, for nondeductibility only if the organization's political-legislative activities are "substantial,"178 the Treasury has extended the section 501 (c) 3 practice of requiring a preliminary applicttion of a substantiality test to section 501 (c) 6 organizations. Presumably, the test of substantiality is the same and, therefore, as discussed above, fraught with difficult problems. ${ }^{172}$ Once the substantiality test is met by a section 501 (c) 6 organization, the regulations contemplate total disallowance unless the taxpayer clearly shows that a portion of his payments are not attributable to legislative activities of the organization. The practical effect of this requirement may often be total disallowance. ${ }^{180}$ But the courts may elect to overricle the regulations. Since some portion of most dues payments to legitimate trade associations undoubtedly constitute an allowable deduction which is refused only because of a failure of proof by the taxpayer, the courts may apply the rule of Cohan $v$. Commissioner ${ }^{181}$ and require approximation of the amount of the taxpayer's allowable deduction. ${ }^{182}$ This approach would necessarily com-

176. Business leagues have been particularly outspoken in their criticism of this regulation. N.Y. Times, Oot. 18,1959 , p. 83 , col. 3 ; id., Sept. 30, 1959, p. 54, col. 3; 15 Cong. Q. Almanac 682 (1959). See also Washingtón Tax Talk, 37 Taxes 1036 (1959).

177. But see Sharp, Refiection on the Disallowance of Income Tax Deductions for Lobbying Expenditures, 39 B.U.L. Rev. 365, 383 (1959); The Supreme Court, 1958 Tcrm, 73 HARv. L. REv. 84, 193 (1959) ("the absolute political equality which the Court found to be within the legislative purpose can only be achieved by a blanket denial of the deduction").

178. Treas. Reg. $\S 1.162-15$ (c) (2) (1959). Presumably the approach adopted is premised upon an intent to treat $\S 501$ (c) 6 and $\S 501$ (c)3 organizations similarly with respect to their legislative activities. But Cammarano might be read to hold that all business expenses for legislative activity are not "ordinary and necessary," and the Treasury might have ruled that all amounts paid to support the legislative activitics of trade associations, irrespective of the extent of those activities, would be nondeductible.

179. See text at notes 146-55 supra.

180. This, of course, assumes that some effect will be given to the phrase "clearly shows." Taxpayer inability to meet this burden is probable. See Thomas J. Barkett, 31 T.C. 1126 (1959).

181. 39 F.2d 540 (2d. Cir. 1930).

182. Application of this rule is apparently within the discretion of the court and cannot be compelled, see Williams v. United States, 245 F.2d 559 (5th Cir. 1957), although Cohan itself might be read otherwise. See generally Gluck, How Cohan Works: Allow!- 
pound the administrative difficulty created by the initial adoption of the "substantiality" text. ${ }^{183}$

Although distinguishing between regular dues payments and special assessments for a specific political purpose raises administrative problems too, the distinction appears justifiable. Customary business league political-legislative activities, for which regular dues payments provide adequate support, are likely to furnish helpful information to the legislature which could not well be obtained elsewhere. ${ }^{184}$ High pressure tactics undertaken to influence a particular bill will less often be financed through regular dues. ${ }^{185}$ In administering the distinction the history of past dues payments should afford a sound measure of "regular,"186 and the contributor could be required to assume the burden of showing that departures from historic dues levels are not in fact special assessments for new lobbying programs.

Admittedly, this distinction might permit a far-sighted trade association to evade the regulatory proscription by maintaining a sufficiently high level of regular dues to accumulate a war chest, insuring against unusual outlays for subsequent political drives and obviating special assessments. This possibility suggests an extension of the Cammarano analogy to section 501 (c) 3 organizations, which, under section $504(\mathrm{a})$, are denied exemption "if the amounts

ance of Binsiness Expense Deductions When No Exact Records Are Kept, 6 Ruteers L. REv. 375 (1952).

183. Administrative difficulties might be largely avoided by ignoring marginal legislative activities in fixing a percentage. But, since most of the legislative activities of a particular business league may be marginal-ostensibly for public relations or education-adontion of this approach might negate the effectiveness of proportionate disallowance. See, e.g., H.R. REP. No. 3138, 81st Cong., 2d Sess. (1950) (The NAM's \$2 million public relations campaign claimed to be totally unrelated to legislation).

184. Business leagues, along with comparable groups, fill at least in part a necd

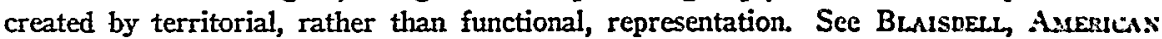
Dearocracy Under Pressure 67 (1957). Their routine legislative activities consist for the most part of providing legislators with information and educating their own members. See Lenhart \& Schriftgiesser, Managenent in Politics, Annals, Sept. 1958, p. 32, at 36-37; H.R. REP. No. 3138, 81st Cong., 2d Sess. 26-27 (1950) ; S. Rep. No. 395, 85th Cong., 1st Sess. 42-48 (1957).

185. Specific legislation often demands intensified effort and more money to support it. H.R. Rep. No. 3138, 81st Cong., 2d Sess. 10 (1950). This was apparently true in Cammarano since the expenditures denied deductibility were in the nature of assessments made by a tax-exempt trade association, see note 173 stpra, and it has been true in most cases involving payments to business leagues, see, e.g., Sunset Scavenger Co. v. Commissioner, 84 F.2d 453 (9th Cir. 1936) ; Mosby Hotel Co., 23 P-H Tax Ct. Mem. 920 (1954); Addressograph-Multigraph Corp., 4 CCH Tax Ct. Mem. 147, 181-82 (1945).

186. Dues are ordinarily assessed at the rate of $\mathrm{X}$ dollars a year or according to a standarized sliding scale. H.R. REP. No. 3138, 81st Cong., 2d Sess. 10 (1950). Thus, for example, the income of the American Medical Association (strictly spealing, a "professional" rather than a "business" group, see note 26 supra) has for some years becn derived principally from $\$ 25$ annual dues, while the National Mrilk Producers Federation's dues are based on butterfat marketed by their members. S. REP. No. 395, 85th Cong., 1st Sess. 46-7 (1957). Variations from such mechanically standardized levels could be easily: detected. 
accumulated out of income during the taxable year or any prior taxable year and not actually paid out by the end of the taxable year . . . are unreasonable in amount or duration" in order to carry out the function on which the exemption is based. ${ }^{187}$ The test under this section has been whether the accumulating organization has a reasonable and concrete plan for the use of the accumulations in carrying out the functions on which its exemption is based. ${ }^{188}$ Application of the same test to section 501 (c) 6 organizations to circumscribc accumulation of a lobbying fund out of regular dues payments would seem preferable to across-the-board disallowance of regular business league clues insofar as they are devoted to legislative-political activities.

In accordance with Cammarano and the "tax equilibrium" concept, it might be argued that a business league should be taxed on the amount of money which it expends for legislative-political purposes. These amounts represent expenditures for legislative activity just as much as did the contributions involved in Textile Mills. ${ }^{180}$ Such taxation would, however, limit the exemption of these organizations on grounds other than those specifically stated in the Code, contradicting section 501(c)6 as an expression of congressional intent.

\section{Nonexempt Single-Enterprise Activities}

The single enterprise, especially the large corporation, often constitutes a highly effective pressure group in its own right, ${ }^{100}$ and, to the extent that expenditures through multienterprise channels are inhibited by post-Cammarano enforcement, this form of activity may be expected to increase. The individual enterprise often makes use of its own personnel and facilities; an office in Washington or in the state capital may be occupied by a skilled lobbyist permanently employed by the firm; public relations personnel on its staff may direct legislative activities; and executives may speak at public functions and contact legislators or officials. ${ }^{101}$ Or the enterprise may employ outsiders such as a law firm, an advertising or public relations organization, or a professional lobbyist. ${ }^{102}$ Furthermore, the enterprise may direct extensive

187. INT. REv. CODE OF 1954, § 504(a).

188. Samuel Friedland Foundation v. United States, 144 F. Supp. 74 (D.N.J. 1956).

189. For example, in 1948 the American Medical Association engaged a public row lations firm to guide its campaign against compulsory health-insurance legislation. S. Rel. No. 395, 85th Cong., 1st Sess. 47 (1957). Ignoring, as did the Cammarano court, the contingent-fee arrangement in Textile Mills, these AMA expenses were functionally identical with some of the expenditures denied deductibility in Textile Mills. 358 U.S. at 503.04.

190. See H.R. REp. No. 3239, 81st Cong., 2d Sess. 26 (1951).

191. The congressional investigation of efforts by the Natural Gas Industry to in. fluence the Harris-Fulbright Bill revealed many instances of this type of corporate activity. S. Rep. No. 395, 85th Cong., 1st Sess. 21-22 (1957) (Socony Mobil Oil Co.); id. at 22 (Standard Oil Company of California which maintains a Washington office with a staff of twelve to fifteen employees one of whom is registered under the Lobbying $A c t$ ); id. at 24 (Shell Oil Co.).

192. In 1958, for example, Covington \& Burling and Weaver \& Glassie, two law firms. registered under the Lobbying Act as representatives of American Can Co. and Atlantic 
propaganda activities to members of its own community-employees, stockholders, credit-card holders, customers--in an effort to stimulate them to adopt its position and put pressure on legislators or public officials. ${ }^{103}$

All such activities could be logically comprehended within the Cammarano policy; indeed, if they were not, avoidance of that policy would, at least by the larger corporation, be relatively easy. But the regulations before the Cammarano Court were not "consistently construed" to reach expenditures for such activities; the Treasury has seldom attempted to deny their deductibility ${ }^{194}$ and, in one relatively recent case, was rebuffed by the Tax Court in such an attempt. In 1954 the court upheld a corporate taxpayer's claimed deduction of amounts expended by its president in connection with two trips to the state capital, one at the legislature's request, to testify before a committee. ${ }^{195}$ The only Treasury denials of deductions for single-enterprise political activities regularly upheld have involved expenditures closely akin to bribery which would be disallowed irrespective of Cammarano.180

Apart from the absence of a consistent construction to afford a firm basis for the invocation of the reenactment doctrine, other arguments are available for not extending Cammarano to single-enterprise expenditures. Just as conspiracies are viewed as more socially undesirable than individual behavior in antitrust and criminal law, concerted activities by several businesses in the political arena might warrant harsher tax treatment and justify the administrative difficulties of enforcing the Cammaramo rule of nondeductibility. ${ }^{107}$

Refining Co. respectively. 15 Cong. Q. Almanac 691-92 (1959). And several ex-Congressmen registered as lobbyists for particular enterprises. Id. at 687-8S. For further examples, see 14 Cong. Q. Alamanac 630 (1958).

193. See S. REP. No. 395, 85th Cong., 1st Sess. $20-27$ (1957); Wood, Corporale Political Activity, 15 Bus. LAw. 112, 114 (1959).

194. See Lucas v. Wofford, 49 F.2d 1027 (5th Cir. 1931) (p3yments to attorney employed to bring about the defeat of legislation adverse to taxpayer's business held deductible); Anthony Cornero Stralla, 9 T.C. 801 (1947) (payments to attorney retained to keep taxpayer informed as to possible legislative action held nondeductible); G. T. Wofford, 15 B.T.A. 1225 (1929) (payments to attorney employed to forestall passage of gasoline inspection law held deductible).

195. Smokey Mountains Beverage Co., 22 T.C. 1249 (1954) (expenditures of corporate president incurred for two trips to state capital; one at the legislature's request, the other to compare a bill with similar bills in other states). The Tax Court appears to have formulated a distinction between expenditures of "legal" and "illegal" businesses. Comfare Smokey Mountains with Stralla, sipra note 194 (expenses of gambling enterprise).

196. See, e.g., Rugel v. Commissioner, 127 F.2d 393 (8th Cir. 1942) (payments to personal friend of state administrator to obtain state business); Harden M(ortgage Loan Co. v. Commissioner, 137 F.2d 282 (10th Cir. 1943) (amounts paid to partnership a member of which was the majority leader of the state legislature to exert political influence).

197. This rationale for limitation of nondeductibility to expenditures for concerted lobbying activity is suggested by recent decisions involvng the application of the antitrust laws to concerted lobbying activities. Riss \& Co. v. Association of Am. R.Rs., 170 F. Supp. 355 (D.D.C. 1959); Noerr Motor Freight, Inc. v. Eastern R.R. President's Conference, 155 F. Supp. 768 (E.D. Pa. 1957). 
When several enterprises combine to form an organization to influence government policy, they may successfully conceal their identity and their financial or partisan interests behind the organizational front; the single enterprise, by contrast, will have considerable difficulty obtaining anonymity. In addition, the single enterprise will not be able to avail itself of the benefits of coordination of effort and pooling of resources which make multienterprise activities a more widespread and effective means of achieving legislative-political goals. In addition, contributions to an outside organization, the declared goals of which will often characterize contributions to it as expended for politicallegislative activities and which could be required to disclose the source of its contributions, ${ }^{198}$ are more easily identifiable than are individual-enterprise expenditures, which may be buried in accounts for operating expenses such as salaries and public relations.

Of course, excepting single-enterprise activities from the rule of nondeductibility might well lead to attempted evasion through multienterprise coordination different only in form from that involved in Cammarano. Single corporations might act in concert with minimal direction from a trade association (requiring no increase in dues) and maintain the outward indicia of individual action. But such a parallel pattern of activity could hardly achieve both maximum effectiveness and secrecy; to the extent that the firms sought the advantages of combination, they would risk detection and nondeductibility.

If, however, Canmmarano is extended to single-enterprise expenditures, the Treasury might attempt to solve administrative problems much as it has dealt with the problem of excessive expense-account deductions. ${ }^{100}$ Corporations might be required to render a detailed separate accounting of all legislativepolitical expenditures as defined by the regulations. ${ }^{200}$ But since the definitions in the regulations are necessarily far from precise, the enterprise could, in most instances, claim that questioned expenditures were not for a politicallegislative purpose. Little reason exists to suspect that more detailed regulations could successfully prevent the burying of political expenses in accounts for operating expenses. ${ }^{201}$

198. The informational return, form $990(\mathrm{a})$, filed by $\S 501(\mathrm{c}) 3$ organizations requests this information. Hearings Before the Special Committee To Investigatc TaxExempt Foundations and Comparable Organizations, 83d Cong., 2d Sess., pt. 1, at 439 (1954). The need for the information to enforce the "tax equilibrium" policy and the fact that returns are confidential, INT. Rev. CODE of 1954, $\$ \$ 6103,7213$ (a), would avoid possible constitutional problems, cf. Bates v. City of Little Rock, 362 U.S. 60 (1960): Talley v. California, 362 U.S. 849 (1960).

199. Corporate income tax forms have been expanded to include a list of questions answers to which will presumably flag possible excessive use of expense accounts. 6 CCH 1960 Stand. Fed. Tax Rep. If 6245 (1960); 12 J. Taxation 141 (1960).

200. Although such questions might elicit information relative to the most obvious political-legislative expenditures, because of definitional difficulties the large amounts spent for marginal legislative activities-"education of the public"-would probably not be mentioned.

201. The problem is analogous to that involved in attempts to prohibit corporate contributions for federal election campaigns. These attempts, embodied in the Federal Cor- 


\section{ConCLusion}

Read most broadly, Cammarano would extend to all of the situations and combinations thereof which have been discussed; a more narrow reading must rest upon often tenuous distinctions. The Court could most logically limit the rule of nondeductibility by holding it inapplicable to expenditures designed to influence the administrative and executive stage of the political process, to expenditures for general propaganda activities not expressly linked to pending legislation, to expenditures by the individual enterprise, and to all contributions or payments to organizations which have been exempted under sections 501 (c) 6 and 501 (c)3. The desirability of so limiting the rule depends upon the weight to be accorded the policies competing with that of Cammarano.

Considerations concerning efficient administration of the tax laws would seem to conflict with a broad extension of Cammarano. Such extension probably would not produce much additional revenue because it would have a relatively insignificant effect upon total taxable income. It would place the Treasury increasingly in the role of enforcing an essentially nonrevenue policy in which it may have less expertise and which may detract from its tax-collecting functions. Furthermore, it is questionable whether even the most painstaking policing of business expenses could be successful in achieving "tax equilibrium" with political-legislative expenses unrelated to trades or businesses. Even if the Treasury, supported by the Court, elects to challenge the deductibility of expenditures routed through all of the channels which have been discussed businesses may be able successfully to disguise these payments. For example, they may be able to make payments in kind-either company facilities or the time of staff personnel ${ }^{202}-$ or compensation in the form of salaries, bonuses, or expense accounts may be paid on the understanding that the recipients will individually make such payments. ${ }^{203}$ In short, the imagination of the businessman may prove a formidable opponent for the diligence of the tax collector. Finally, even the most diligent enforcement may founder on definitional problems because the types of expenditures for which deductibility would be disallowed under a broad reading of Cammarano are especially untesponsive to precise characterization.

A broad reading of Cammarano would also conflict with a policy of maximizing the flow of information and ideas within the body politic and to the organs of government. Many have contended that business groups should be encouraged rather than discouraged from making their views known to the

rupt Practices Act, have "hardly dented corporate influence on federal elections" according to Bicks \& Friedman, Regulation of Federal Election Finance: $A$ Case of Misguided Morality, 28 N.Y.U.L. Rev. 975, 995 (1953).

202. Firms in the natural gas industry contributed both employee's time and company facilities to organizations formed to conduct the campaign to promote the Harris-Fulbright Bill. S. Rep. No. 395, 85th Cong., 1st Sess. 20-27 (1957).

203. Cf. McKean, Party and Pressure Polttics 353 (1949); Mirrial \& Goswejl, The American Party System 406 (4th ed. 1949). 
electorate and to legislators, administrators, and executives. Only when the public and responsible officials are fully informed concerning the potential impact of alternative policies upon interest groups most directly affected, it is said, can a government based upon consent function most effectively. ${ }^{204}$ With increasing government intervention in the economy, the views of businessmen may be more necessary than ever to assist Congress and the Administration in tailoring their policies to the needs of a complex economic system.

An alternative approach, more in harmony with this objective of maximizing the flow of information and ideas, would be to redress the disequilibrium between political-legislative expenses which fit the mold of business expenses and those which do not by increasing the deductibility of the latter. The imbalance could be partially restored by a liberal interpretation or abolition of the section 501 (c) 3 limitation on political activity. ${ }^{205}$ Thus organizations, contributions to which are generally not deductible as business expenses such as the American Civil Liberties Union or the NAACP which are denied exemption under section 501 (c) 3 because of this limitation, ${ }^{200}$ could receive deductible contributions on an equal footing with business leagues and trade associations. Alternatively, or in addition, all taxpayers could be allowed to deduct up to a specified amount for political activities from their individual returns, putting them on a par with the businessman who would then be allowed to set off expenses for political activities against earnings. ${ }^{207}$ This appronch to "tax equilibrium" might be more successful than the Cammarano policy of limiting business deductions because of the problems inherent in implementing that policy.

On the other hand, it could be persuasively argued that the revenue laws afford an improper means for dealing with problems of private influence on the political process, ${ }^{208}$ problems which warrant more than the piecemeal treat-

204. See Celler, Pressure Groups in Congress, Annals, Sept. 1958, p. 1; Lcnhart \& Schriftgiesser, Management in Politics, id. at 32.

205. Devine, Pioneers or Propagandists?, 29 Survey Grapaic 348 (1940).

206. See J. T. \& Emma Lowe, 21 P-H Tax Ct. Mem. 451 (1952). Contributions to the Legal Defense and Education Fund of the NAACP, a separate subsidiary, are, how. ever, deductible. Comment, 58 Yale L.J. 574, 581 (1949) ; 102 Cong. Rec. 15030 (1956) (remarks of Sen. Stennis).

207. A bill to accomplish this for certain amounts contributed for federal elcction campaigns was recently introduced. H.R. 1980, 86th Cong., 1st Sess., 105 Conc. REe. 377 (1959). Numerous similar proposals have been introduced in the past. Sce, c.l., S. 2302, 84th Cong., 1st Sess., 101 Cong. Rec. 9057 (1955) (proposing a $\$ 100$ cciling); S. 2497, 84th Cong., 1st Sess., 101 Cong. Rec. 10277 (1955) ( $\$ 50$ ceiling); H.R. 9558, 84th Cong., 2d Sess., 102 Cong. Rec. 3423 (1956). For a discussion of these and other proposals, see Peters, Political Campaign Financing: Tax Incentives for Small Cointributors, 18 LA. L. REv. 414 (1958).

208. The purpose of the tax laws is not, after all, to reform men's moral characters. 50 Cong. Rec. 3849, 3850, 4613 (1913). Three bills have been submitted to Congress to overrule Cammarano by amending the Internal Revenue Code to permit tax deduction for certain "lawful" lobbying expenditures. H.R. 7123, 86th Cong., 1st Sess., 105 Conc. Rec. 7378 (daily ed. May 14, 1959) ; H.R. 10272, 86th Cong., 2d Sess., 106 Cowo. Rec. 2093 
ment accorded them by the current pattern of statute and judicial decision. According to this view, "tax equilibrium" in the political realm, pursued by denying business deductions or by increasing nonbusiness deductions, is an unrealistic objective; it raises virtually insoluble administrative problems, places the Treasury in an inappropriate role, and removes incentives for more comprehensive means of dealing with the problem. After considering these alternative means at great length, ${ }^{209}$ Congress decided upon a procedure requiring full disclosure-the Regulation of Lobbying Act. ${ }^{20}$ Rather than supplement this act through tax policy, the registration and disclosure requirements on both state and national levels could be broadened. ${ }^{211}$ Thus, abuses could be remedied without tampering with the Internal Revenue Code and without inhibiting the flow of information and ideas.

(daily ed. Feb. 9, 1960) ; H.R. 10502, S6th Cong., 2d Sess. 106 Coxa. Rec. 2592 (daily ed. Feb. 17, 1960). See 18 CoNG. Q. WeEkLY Rep. 572 (1960).

209. See S. ReP. No.o. 395, 85th Cong., 1st Sess. 201 (1957).

210. See note 206 supra.

211. See Zeller, The Federal Regulation of Lobbying Act, 42 A3r. Por. Scr. Rev. 239 (1948). 